\title{
ウイルス性疾患に於ける封大体のbiology関する研究 *
}

第 3 報エクトロメリア・ウイルスーエールリツレ

癌細胞系に就いて**

土肥 清一苂*

\section{SeItTi DoHi: STUDIES ON THE BIOLOGY OF INCLUSION BODIES IN VIRUS DISEASES. (3)}

[受稿 6 月7日 1955]

\section{I. 序}

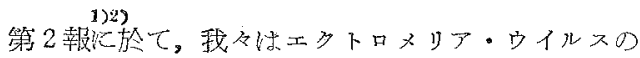

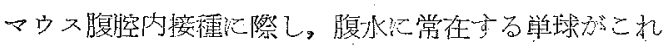
に親和性表有し，併も此時以容易に胞体内に封入体を 形成する事を報じた。苃此嗄水穿刺によつて得られた

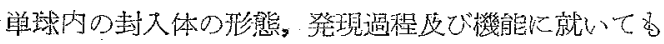

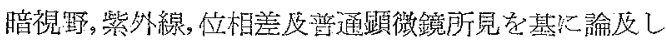

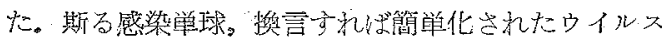
・宿主細胞稀が新にもたらした实験上の利点は，人工 産物の介入する余塯のない無㑺の単離細胞内のウイル ス増殖像の観察を可能ならしぬる腬でるつた。更にこ の細胞の腰腔中に於ける浮游状態は液状培时据培盖さ れる細菌にる比較され，往つて細菌ウイルスによる各

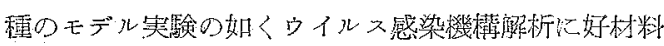
を提供する加炕見充大。然已乍ら，二匹の小重物加ら 得られる腹水は高々数滴に嗃ぎないために，経時的な 形態学的観察より進んで，更に，ウイルス增殖態度を 量的に取报う重的な实験に入ることは一応晃送りの状 態に岁つた。

一方，腫湟細胞か゚ウイルスの好宿主たり得る雪は， 既に Levaditi and Nicolau (1922) 以来，幾つかの郝

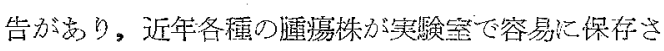
れると共にこのう面の関心が再び高类つて来た。即ら マウス肉腫180なる莯に就いて, Tunner and Mulliken (1947) が牛痘りイルスが，又 Moore(1949) がRus"

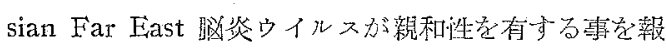

じ，㕛組織培㙓法を用いては、この方面賞用されて いる He La 細胞分離者の Gey は Bang と共心 1952

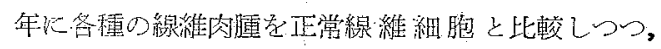
Easte:n equine encephalomyelitis ウイルスに刘する

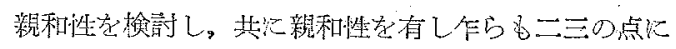

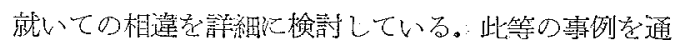

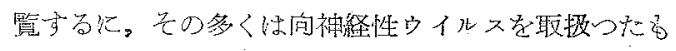
のであるが，特我々の注意を惹いたるのは、マウス 腹水中で増殖するェールリッ七癌に就いての知見で㐫 る。即方 Acikermann and Kuntz (1952) は向神経性 インフルェンザNWS株の漞和烍莸訳明し, Koprows$9.10)(1)(2)$

$\mathrm{ki}$ 一派は10数橝のウイルスを用いた広籍な実験から

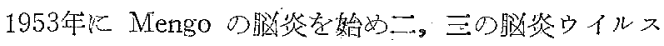
の増殖を見出した。

橎つて, 若しェクトロメリア・ウイルスがこの遊離 㵋細胞内で增殖し得るならば，腫瘍沺胞の持つ自律的 な舆限の增殖力を刺し得て，腹水単球の笑驗に於て遭 遇した量的不足の第一障棏は少くとる-応笑破出来よ 5。既以我々はエクトロメリア・ウイルスが皮膚上皮

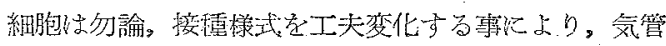
上皮，腸上皮夫々の細胞内に封入体を形成しつつ増殖 する高㹂の问上皮性を特徴とすることを経験してい る. 幸にエールリッヒ㰒細胞内にェクトロメリア・ウ

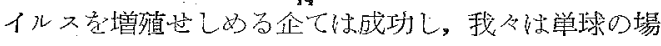
合之同㴚火，胞体内封入体を形成しつつ増殖する知 見索得る事が出来た。斯らマウス腹腔中で $10^{9}$ 個炕達 し得る細胞を舞台にエエタトロメリア・ウイルスの細

* 本研究には文部省科学研究費の補助老得た。

**本報の内容は昭和30年4月2日第3 回日本りイルス学会に於て報告した.

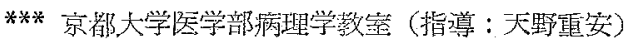


胞内增殖態赛を再び詳細:検期する端緒を得た。

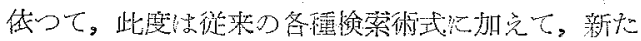
に超薄包片の電子顕微鏡像による形態学的観察皮び感 染細胞の数量的変化等江基いてウイルス堌殖態变を検

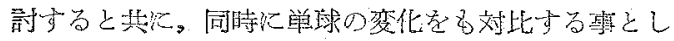
た。

\section{II. 材料及び方法}

使用ウイルスは能報と同じく, マウス腹腔内接酤心 よつて2万至 3 日で死しした脬乳で，生理的食塩水

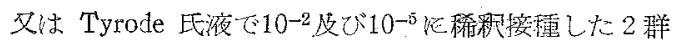
に就いて实験を行つた。

使用動物は我々の大手出来た $\mathrm{nA} 2, \mathrm{DNK}$ なる二系

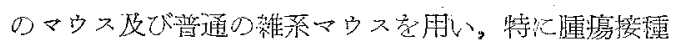

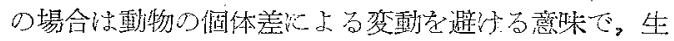
後約10週の雄性均一系マウス定使用した。

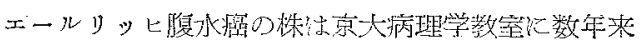
保存されているもので岁る。

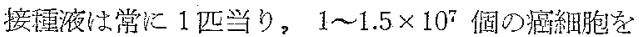

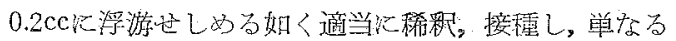
睡癔累代の場合孔大体同样量老用いた。斯くて，接種

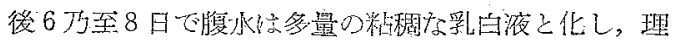

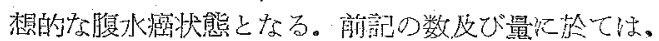

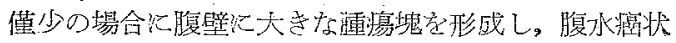

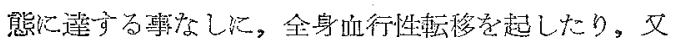
は非常に遅れて腹水内增殖麦示したりする等の成續の 不統一を筧れるべく経験的炕余裕を持た地て決定した 我々の基淮であり，接種皆後の一恃的減少る防止可能 で㐫る。㤯10日以後炕至ると，血液泿入に上り，腹水 は次第炕桃色加ら紅桃色へ之変化し，白血球混在及び

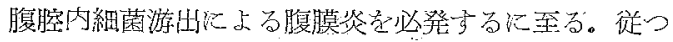

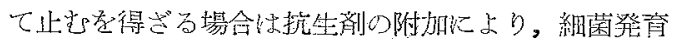
学押えて使用したが，可文的斯かる材料は集却した。 以上に上り，自発的癜細胞心減少。消失は㱠ど経験し

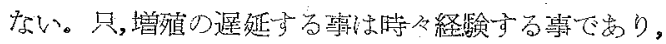
マウスの系統を变光ても大同小異の感が強くこの点 の詳細な分析は今後追求すべき閐題で岁るが，動物の

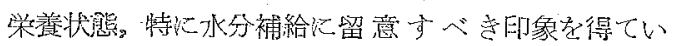
子.

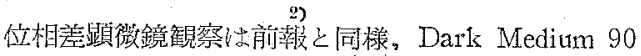
倍油浸対物レンズを使用し，超生体で行つた。

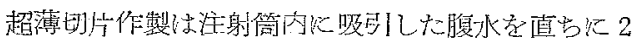
\%オスミウム䠁及びベロナール緩衝液（$(\mathrm{pH}=7.2 ）$ 等:
量の固定液厄 1 持間混じ，遠洗後水洗，脱水を経てnbuthyl methactylate 比埋し。小林島津型ウル下ラ

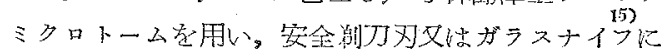
て大凡 $0.05 \mu$ 前後を目標として或断した。観察は原則 として包埋剤末除去のま栾行つたが, 時に除去を行い， クローム蒸着圾料とした。この場合酷酸アミールを用 いた。（本稿の写真説明には除去試料の場合比の久と の旨を附記した)。使用電子顕徽鏡は毁津 C-2 型及び 日本電子光学 JEM-5C 型で1900万万至3500倍で撮影し た。

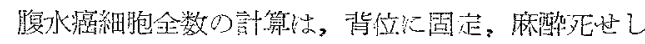
めたマウス腹水壳注射器比て吸引し，赤血球用メンヂ

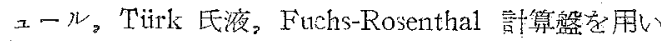

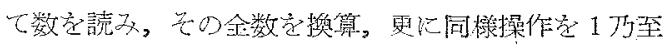
$2 \mathrm{cc} の$ 生理的食㙁水の洗涤液炕就いて行い，通坌 5 回

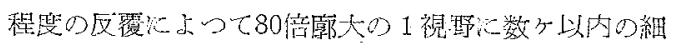
胞数心達すれれ゙腹壁を開き。後膜膜附近汇残留世吕細 胞起更飞洗い, 前述の如之細胞消失迄算定し, 総和在

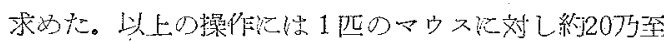
30ccを要する。同時以塗抹ギームザ染色炕よる細胞分

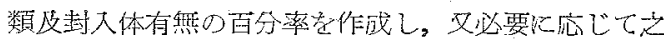

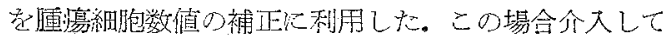
来る誤差压子として达の三点考考虑好祆ばならない。

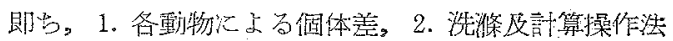

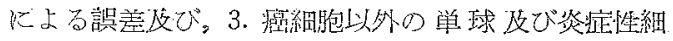
胞，特飞好中球の関与の三点で毒る。この中，2.3. 火

Text-Fig. 1. Quantitative changes of Ehrlich mouse ascites tumor cells after ectromelia vitus inoculation.

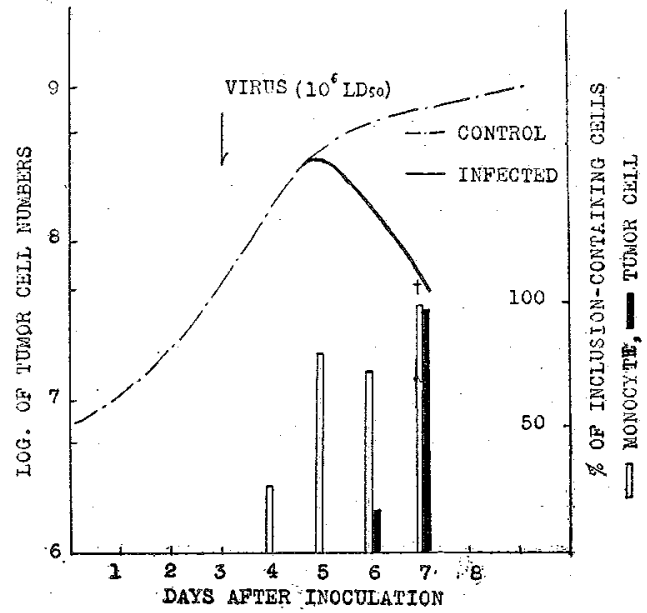


Text-Fig. 2. Quantitative changes of Ehrlich mouse ascites tumor cells after ectromelia virus inoculation.

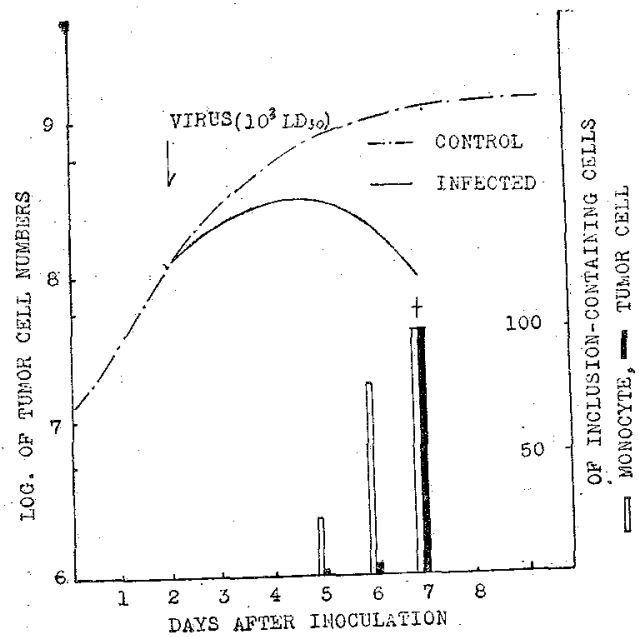

関する諄差は Klein and Révész (1953), Lucké and

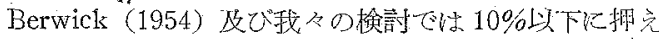
られるが，個体差は Lucké 等は15\%，Klein等は33.3

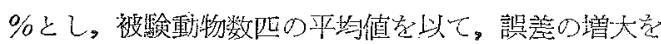

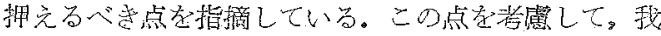
々は 2 万至 5 匹のマウスに就いて計算值炎plotし, 正

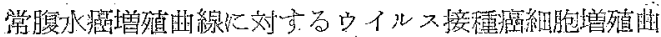
線の意義を検討し，少くとも:1/3 以下の差走以て堌殖

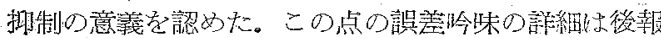
の予定で㒸る。

\section{III. 成}

績

\section{1）ウイルス感染腫瘍細胞数の腹腔に於ける数的消} 長 (第1.2図)

$10^{7}$ 個内外のエールリッ七癌細胞を腹腔心移植与れ

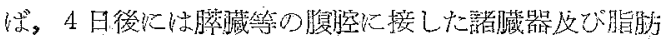

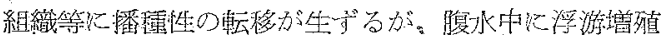

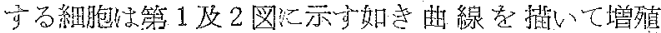

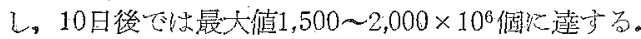

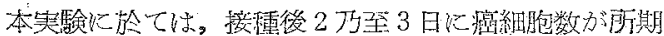

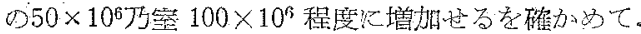

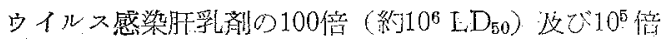

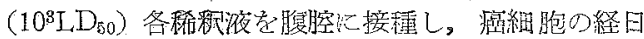
的な数量的消脣老調べた。

第 1 文び 2 図以示した曲線がそれで岕る之に依れ

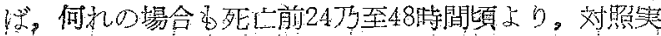

験と比䡆して，我令の設定した30\%の正党変動域老招

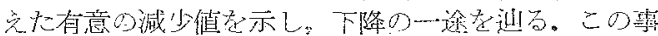

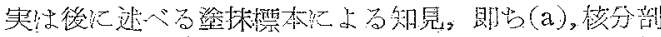

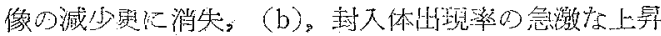
及びをによる細胞変性像の出現と時期的な一致を示 しウイルス感染炕るェールリッヒ癌稩胞発育障碍

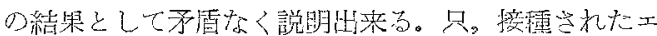
クトロメリア・ウイルスはエールリッヒ癌細胞の外に

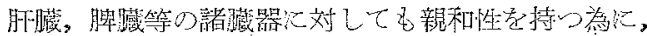

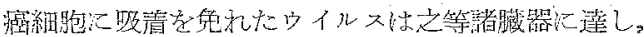

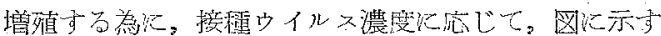

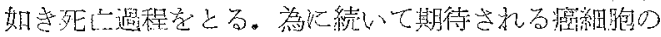
歾的な減少期比迄追跡し得なかつた。

\section{2. 蒤抹標本による観察（管1,2図）}

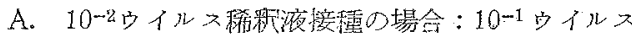
液接䅜の䟢，单球胞体内封入体の出現は 673 至 8 時間 後で要るた刘し。この場合法24時閒後に至つて, 等球

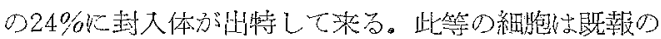
如く，胞体の好程基性が失示れ，胞体は稍膨化し；変

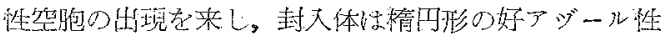
物質として，胞体の辺縁部出現して来る。一方ェ一 ルッッヒ癌細胞中，首球との比率，核分剖像子殆ど正 常堌殖の籍圈内に止り，細胞の形態も正常で，好塩基 性強く，㱠ど脂肪変性媔粒の出現も認めない。48时間 後には単球の封入体は增加し，76.9\%に達する。エー ルリッヒ癌緦胞以於ては，単球との比率度び核分剖像

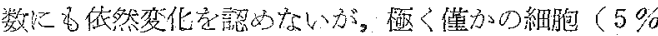
内外）の胞体内以単球のそれと殆ど同性格の封大体の 出垷老見るた至る。此封入体は直径約 $2 \mu$ 立のアッ゙ール

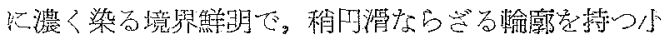

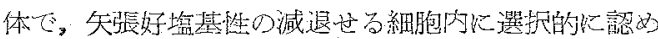

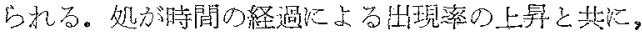

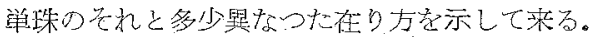

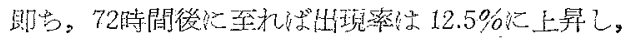

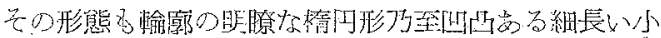

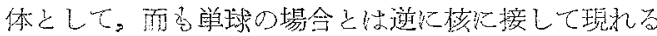

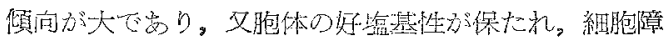

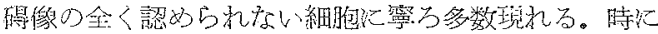

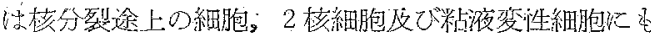

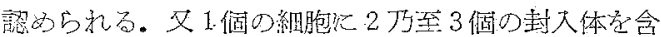

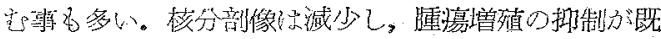

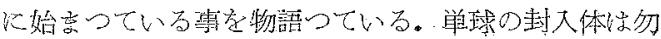
詇堌加の一途を辿る。 
斯くて動物な4 日前後汇落死するがこの時期には単 球，エールリッ七癌細胞其飞 $100 \%$ \%近い封入体出現

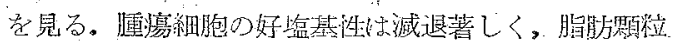

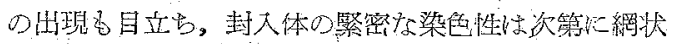
飞淡くなり，周园之の境界も次第に不鮮明となる。

斯る眭期沉於て，好アッ゙ール辣大体内部飞特有な変 化が出現する。即与直径 $2 \mu$ 前後の円形乃至榜田形の.

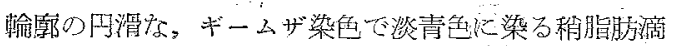

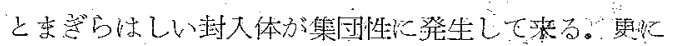
時間が経過寸狄ば，好アッ゙ール封入体が減退して行く

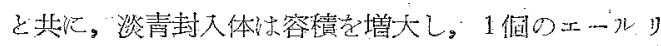

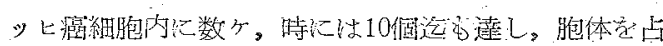

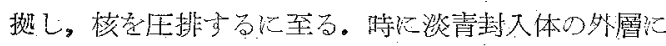

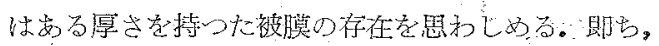
感染後期代於て，好アジール封入体の内反文び之に接し

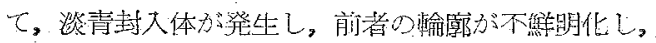

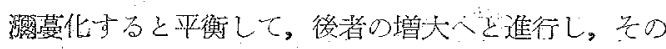

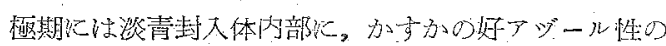
小粒子の見極的得るるの子无琴われる。

B. 10-5 ウイルス稀譒液接種つ場合：エールリッ七 癌細胞の 1400 万個を移粗して2 日後厄10-5口イル六移

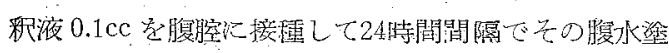

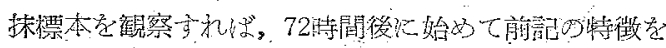
示す封入体が先ず単球に出斑する。即占単球の20\%

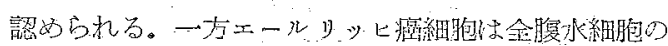
93.7\%を占めるが、封入体はその $0.48 \%$ \%証影され， 文核分剖像舟 $1.44 \%$ 之略正常増殖時の值を之る。96時

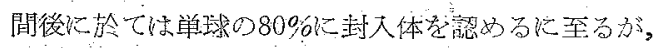

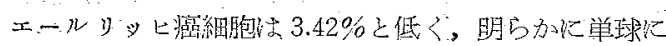

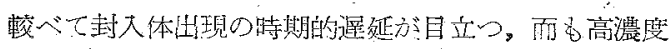

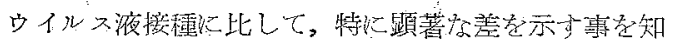
子.

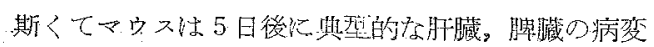
を呈して死亡するが，この期に至ればエールリッ上癌

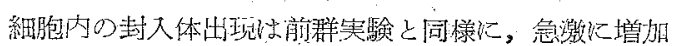

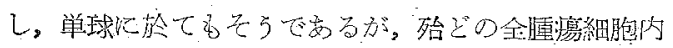
に現われ，而子遥加多彩な像老呈する。即台，1個 の細胞内にる2 乃至 3 㮯の好アジール封入体文び溥青 々染る円剘乃至陵円形の前記淡青封入体を创含与るる のが多人，此封入体の胞体内位置马前述の如く，単球

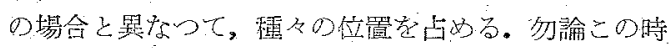

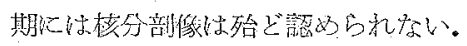

今上記 2 輜頪の封入体の活現也る腹水塗抹標本を

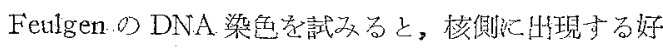

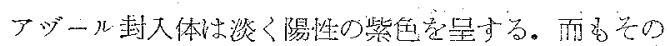
陽性度はアジール出調の浱淡化比例し, 後者が洞蔓性 で染色性が微弱にな机よ゙，Feu1gen 反応尼殆ど顕微鏡 钼察に排りて来ない。単球の場合も略同様の結果学得 た。一カギームザ液に淡青く染る封入㑣は漼抹標本の Feulgen 染色では陽性成續杂得ていない。即ち，濔蔓 性汹なり，Feulgen 反应弱:昜性炕なつた好アッ゙ール封 大体汇接して，企く陰性の滴状物としての存在が指摘

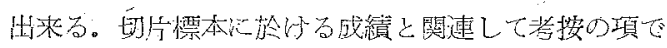
で再び触猄るが，雭化角 Feulgen 反応は同一細胞に 於て，好アヅール封入体记は史陽性火，淡青封入体炕は

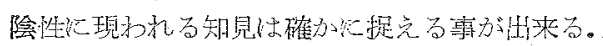

\section{3. 位相差顕微鏡による観察}

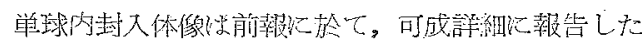

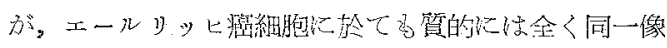
を呈する。只叙抹標本で指摘したと同じく，2万至 $4 \mu$

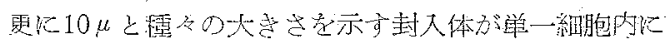

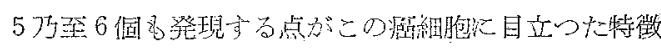
で岕る。勿論气の何机子等しく关の内部乃至表面枃 一の大きさ接うたウイルス粒子が充满して見える。

\section{4. 雷子顕微鏡による超薄切片の観察}

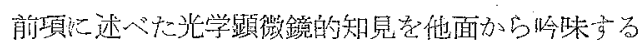
目的で，各時期伦於け当エールリッ七瘦細胞のエクト ロメリア・ウイルス感染像を電子顕微鏡学的汇観察し た。本方法では 15 万至 $25 \mu$ 位の直径学有する癌細胞

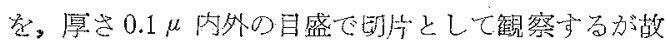
飞。飽く迄も細胞の溥い一断面累るに止る点定像の 解粎炕当つて留意世放ぱならない。

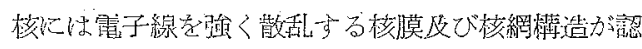
められ，特所謂 marginated chromatin 像が顕著で

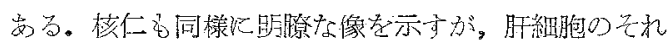

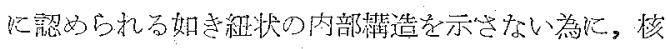

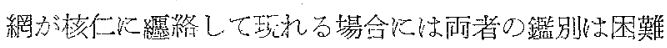
となる。核の外形は切断される場所化っって, 当然大 小反び形態が種ふで女る。胞体内比散在する糸粒体は

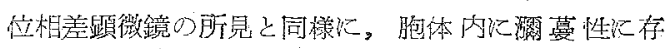
し，位罱的には胞体辺緣部に存子る。大凡桿状の形態

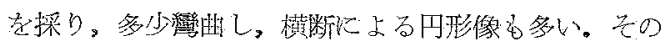

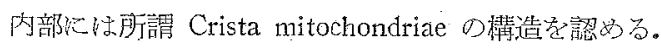
苘，胞体の一局処仁曲折して紐状の濃く，太い線維構 造が大凡平行して出現し。多くの場合周国炕系粒体が

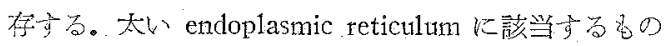


て，末端は盲端で笠状㕛圼するが，乙の固々の線維は

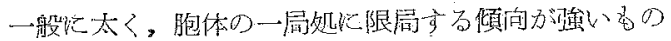

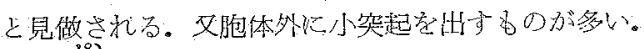

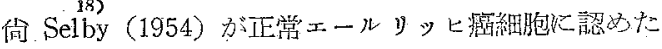
closed-packing 排列䒚採る $60 \mathrm{~m} \mu$ 大り均一な粒子像な るもの学我々は認めた経歌はない。

䏌，好アジール封入体を出現也しめる感染初期の癌

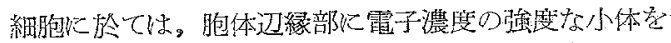

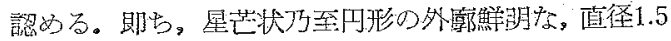
$\mu$ 内外の小体が数眛存し，一船に攵の未梢部が中央部

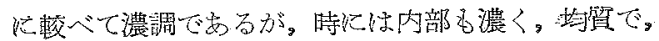
内部に特別な細櫵造を認めない。時に $200 \times 100 \mathrm{~m} \mu$ 程

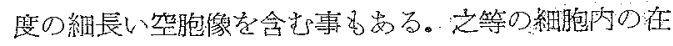
り方は孤在性で，いづれの細胞有形成分と账置的な

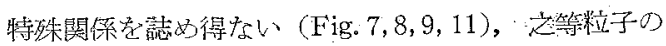

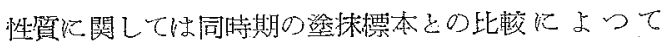
(Fig. 1,2) ウイルス感染に特異的変化ではなく，変

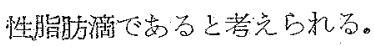

次以該時期の細胞心認められる最る注目すべき所見

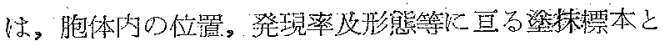
の比較によつて，前記脂肪颗粒と区別され，好アジー

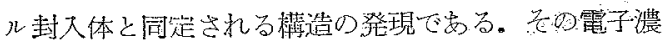

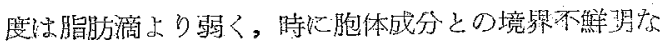

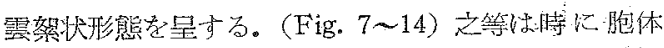
辺縁部に出現するが，多くの場合核に泌接した位置を

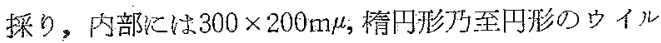
ス粒子が散在するが，之と同大若しくは粭大にして，

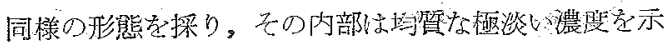

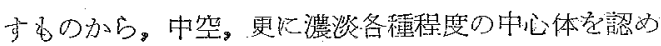

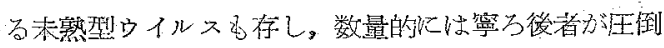

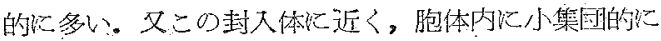

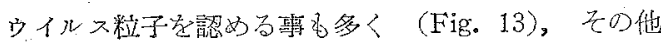
Fig.9の如く，散在性のウイルх像をる認める。この 他 Fig. 14では $150 \times 100 \mathrm{~m} \mu$ 大の中空円形心稳四形粒

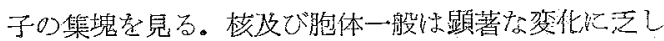
$く$, endoplasmic reticulum の出現は呮弱で, 系粒体 は封入体周囲以高密度に現れ，軽度の膨化子示方場合 的为布。

続いてギームザ染鼠で淡昰の小封大体が出玨して来 る。脂肪滴の存在は前述と略同様で要るが、雲絮状の 好アジール封入体烧して，又はその内部に遥か濃

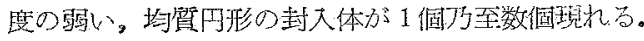
その位置的関係からギームザ染色以よる淡青封入体の

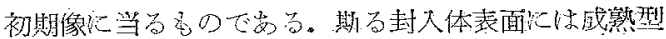

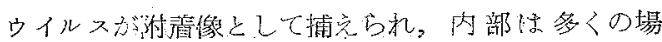
合，未犬゙全く無棈造に止委つているか，時に600〜750

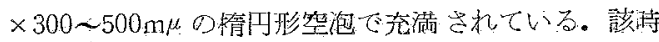
期の核收び胞体成分の性状は72時唒後の々れ䀩等し

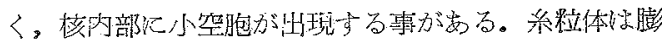
化し，前記二種封入体火接近する傾向を示与。endoplamic reticulum 胞䏩一呞処代認められる。

感染極期に達すれれ゙，淡青封入体がギームザ染色で 多数現われ，殆ど全細胞の90\%上上が球大体を含有す

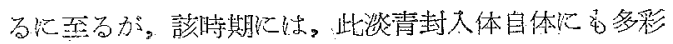
な電顕的满造が指摘されるに至る。

先に述ベた中等度の電子濃变を有する好アッ゙ール封 大体は次第減量し，淡く，その境界子益々不眀瞪と なる傾向を示すが，内部には低然篎些を主としたウ イルスを㩁している。而してをに接する所謂淡青封入

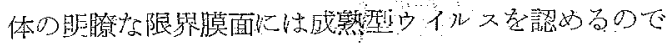
安る。往つて封大体の埥造と関連七てウイルスの増殖

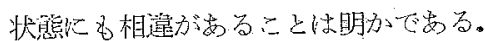

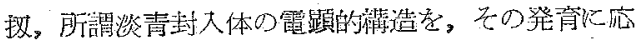
じて今少しく詳述する。即占，(A) \& (Fig. 13，15， 16)内部队ウイル久を含李ない淡い竘望の基筫からな

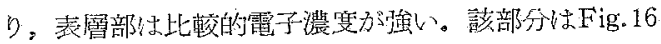

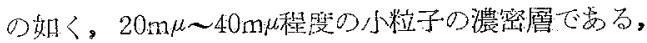
この型に属するものでる, 被膜にウイルスの泛しいる

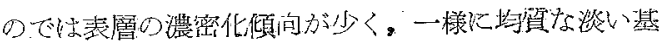
筫のみて權成されている。(B)。(Fig. 17, 19) 次长 (A) 型と同様に中心部反び束椎部が電子濃度の明確な

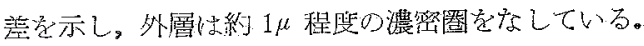

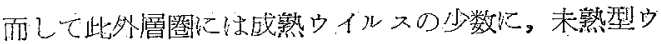

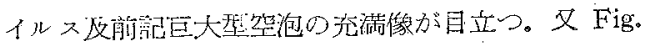
190如く，殆ど成熹䍿ウイルスに依つて占められる場

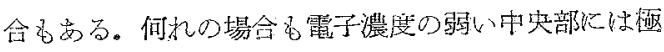
少数つ成熟型ウイルス散有像学哂めるに過ぎない。次 K（C). (Fig. 18) 沫梢部の容秷が更に增大し， E大 冧泡の密度も益々増大し。中央部の成熟ウイルスも相 刘的隍加表示している。更に (D). (Fig. 14, 20,

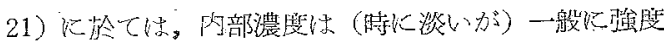
の傾问を示し，(B)，(C) の外層圈の濃密状態无平等 飞封入体内部に行さ渡つた溙柏を示す。時见封入体被 膜輸廓の品嘹を钭くものも存する。(Fig. 20) その内

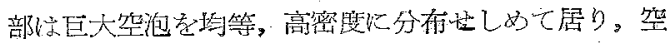

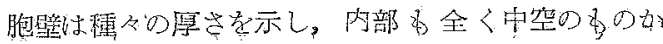




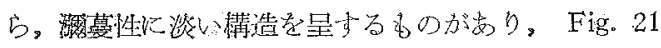
の如くその壁は漲密部の基筫形成粒子と略同大なもの が薄排列学している。次比（E)（Fig. 23，24）内部 り濃度が均質一様に高く，その内部に成熟型ウイルス が多数散在し，基質化埋没されている。この場合似は

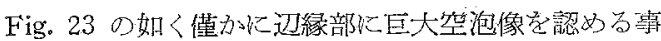
も岁るが，基質の濃度が増加するにつれて減少し，又

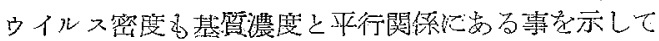
いる。

以上の如く，淡青封入体も電頭的観察化よつて大体

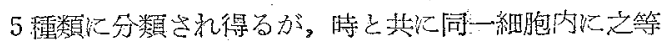
が各種の組合せとより出現し，好アッ゙ール封入体と組

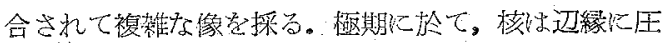
排され勝ちで，標本上では核を外れた細胞筫像に接す

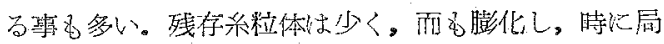
処的な endoplasmic retict1um 像を見る。その他一 般火胞体棈造の網状の荒れた感力゙強い。

\section{IV。総括的考按}

\section{1. ウイルスと癌細胞との増殖拮抗}

ェールリッヒ癌細胞とウイルスの関倸を 13 種の向神 経ウイルスに就て調ベた Koprowski 等（1953）火倿

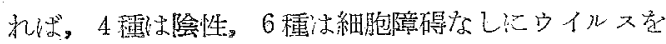
増殖也しめ, West Nile 脳炎, Mengo躯炎, Bunyanwera の 3 種りイルスが同細胞内て增殖し，著しい障 碍，変性老浓起する点老指摘している。Ackermann 等（1952）るインフルェンザ向神経性㧣で細胞の障碍 による滅少を報じ，永田氏 (1954) の缒試も同様の絬

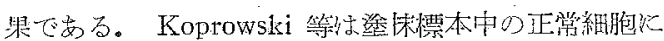
対ずる腫湯細胞の比を。永田氏は $0.1 \mathrm{cc}$ の腹水中の細 胞数を以て前記の結諭伦達している。そのデータの甚

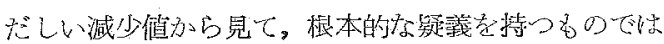

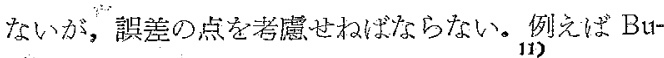
nyanwera ウイルス実験汇於敄る Love 等"(1953)の

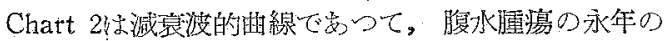
研究家 Klein の咸烧摘している様伦全細胞計算が 望ましい。

双，エタトロメリア感染エールリッヒ滛細胞は確か

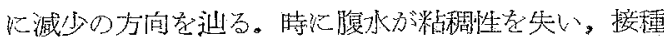

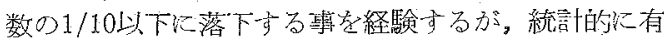

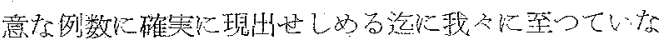

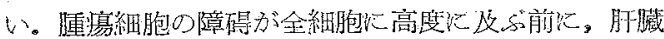

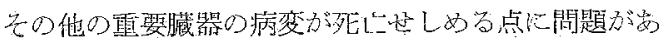

りっこの点の土夫を試みつつ䨘ねて実賖を続けてい る. 更に今一つの原因として封大体の形成が細胞障碍

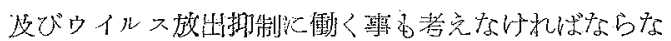
い.

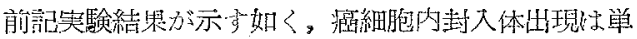

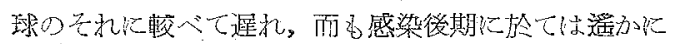
大型の而も多数の封大体を出現过しめる。一方腹水細 胞内少イルス量は24封間で明らか圮增加家し，逐

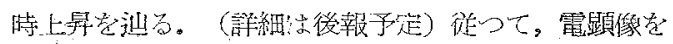
る考愿して，封入体堌加はウイルス量のそれと考光て 差支党はない。

而らば，単球文び活細胞の封大体像の発現期のずれ

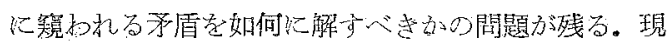
在我々はこのデーターを説明し得る段階に達していな いが。作業伋説として代謝拮抗の概念を抱いている。 朗ち。腫瘍と云光ば発育力がとりわ斿て問題となり， 正常細胞汇比輘して組材合成の異常立進方特質とい兄 る。斯る特異な新陳代謝系化ウイルス感染が起つ炎場 合,ウイルス合成系との間炏当然競り合いが起るもの と考完られ，而尾これが此較的合成力の弱い正常細胞 上りも激しく展開过れる事性想像火難くない。加く て。一旦ウイルス材料合成の方向化転向せし女られれ

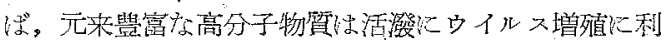
用されて行くのではないかと渚光られる。勿論ウイル スの栄養要請因子似対する教慮が抁われるべきことは， 当然で㐫るが，腹水細胞封大体所見の解釈として，一 応の我㣻の予想を述べた。

\section{2. 癌細胞内ウイルス封入体のギームザ染色性}

エールッッヒ澏細胞火出現するェクトロメリア封大

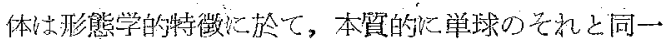

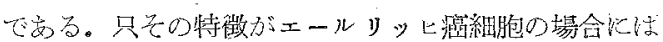
特以強謂されている。即ら，ギームザでアジール以染 る所謂好アジール封入体の出現炕崌れて淡青焦均䝷に

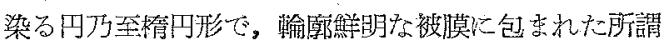
淡青封入体の出現がそれで㐫る。この両者は染色性が 異なり，而も同一細胞比同時灿出現し得る事は確実て

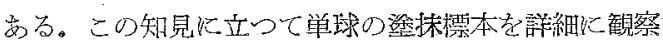

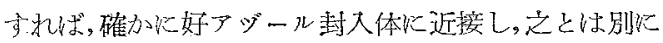

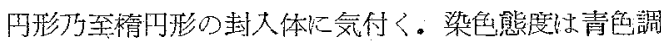
が更に微弱で、時には殆ど不染性でアルるール固定で 流失した非特異性変性脂肪顆粒の报け款との鑑別は容 易でなく，我々は雨封入体関係の明かなェールリッ七

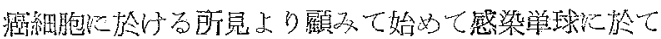




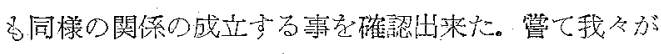

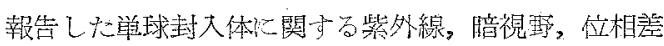

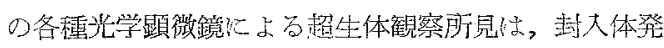
現初期の 8 14 時間のるのは別として，乙の大部分は 好アジール封入体自身では柿く，淡青封入体のそれで

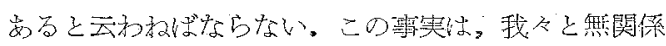
ぐェトロメリアウイルスダェールリッヒ瘦絸胞度ぴ

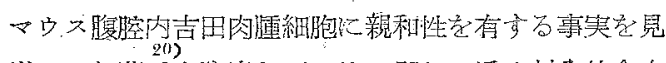

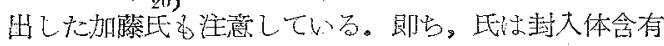
細胞をギームザ染色で確認，マークした後に脱色し， ヘマトキシリン・エオデン染色を施し，淡青封入体が 好エオデン性で，好アヅール封入体性此際不染で要る

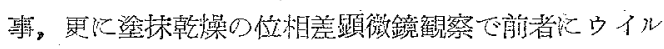

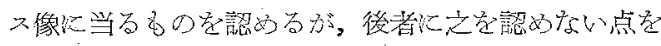
挙げ，天々にA琹，B䍿の名称学与壳ている。確か心 淡青封入体はギースザ染色時に好塩基性に非ざる構造 物て，例完ば Russell 小体の如きも亦ギームザ染色時

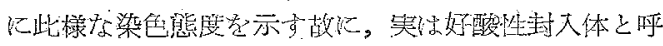
ぶのか秷当である.5。立に対し好アジール封入体は核 酸の存在と関係することが多く、此物持通常のへマト キシリン・エオヂン染色時に必ずしす强湓基性を発掩

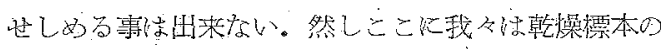
位相差顕微鏡観察では，招生体の湿潤材料に比較し て, 位相差效果が䓕だしく減弱することを指摘したい。

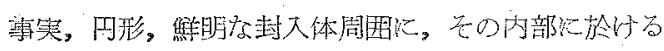

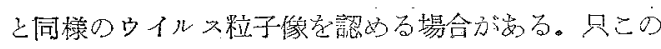

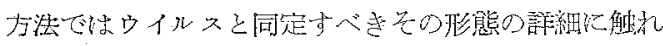
る專は解像力の限界学超えるので，封入体とは無閔係 のウイルスの存在に就いては断定孝控光るべきと考光 る。倫ウイルス感染皮膚表皮細胞を淕抹ギームザ染色 で観察した場合にる前記二種類の封入体力瀻別され得 ることも我々は裣討している。

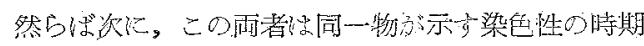
的相違による像か，或は全く異質的物賀厄要るか力問 題となる。この点に就いては好アッ゙ール封入体内部に

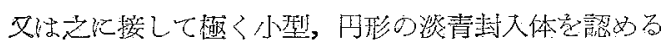
所見から案じて，後者の見解意採るが，両者の関係以 対する回答はしかく䌪単なものて度ないと考光られ

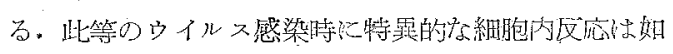
何なる過程をとつて発展し来るであるらか。それには

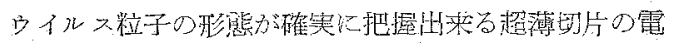
子顕微鏡像を基として解析起進めなければならない。

\section{3. 癌細胞ウイルス封入体の䨖顕的㭘討}

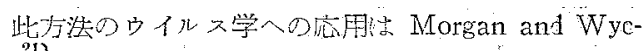
koff (1950) 以来活潑任行れ，最近の技術的進步は 影著なるのであるが，中でる牛痘及びェクトロメリア

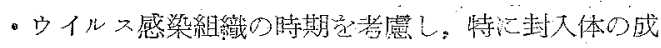
立過程に就いては我尽と㱠ど同時区同稼の結論を得た Gaylord and Melnici (1953) の柴靕方注目される。

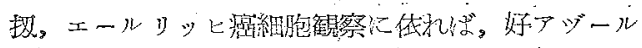

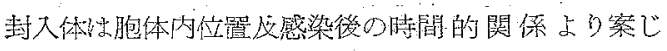

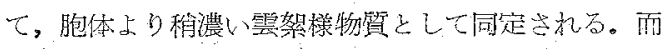

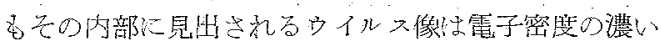

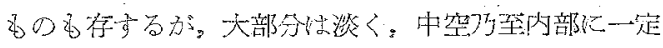
の檴造を示すものである。この後者の意味に就いて

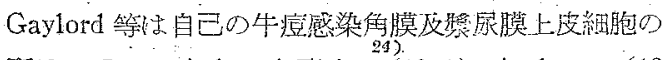
所鬼飞 Leventhal and Fisher (1952), Anderson (19 53) の緭藏ウイルス放び Schlesinger and Werner (1 952) のインフルェンザ不完全ウイルスの知見を加光

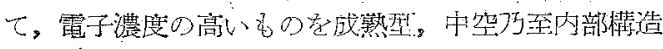

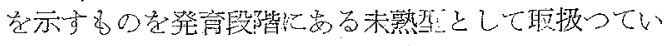
る。前述の好アジール封入体は形態学的洊等の指摘 した matrix region $と$ 全く一致し、自时期的にもこれ が正しく早期灶出琴する整实からして，この見解を文 持し度い。Dawson and MeFarlane (1948) は精製し

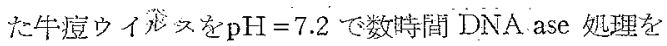

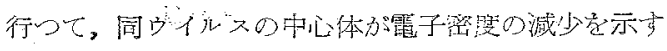

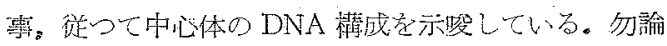
細菌ウイルスから得られた一般通亚に低れば，核酸他

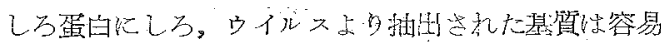

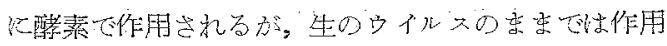
され難とといれている点老䒜視するるのでない が，彼等の知見は我々の掝つ形態学的材料の説明に好

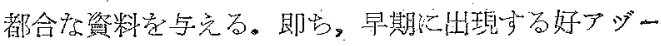
ル封入体内或の中管のウイルスは来䰻型てDNAの稀

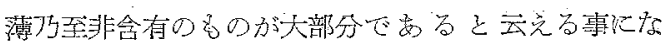

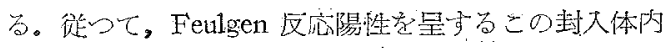
のDNA部分はウイルス自身の DNAでなく，賞ろ細 胞側に属す物筫に然ならない学となる。

ウイルスと核酸の閆題に詳細を極めた研究預域であ るが，非態学的考慮が茅朴で要つれ為に，ウイルス感 染細胞の DNA 物質の出現を直らにウイルスそのもの と同定した确究者加多心。Hydén (1947), Caspersson (1950) 等加々 5 て㒸り，Wolman (1954) \&同様立 場加ら日イルス依らない封入体との相違学 Feulgen 庈五の陽性，陰性で分類している。賞て得た我々の紫 
外線顕微鏡亡よる封入休所見 (1951) そ $\operatorname{Scott(1950)~}$ の Feulgen 反応の精是とウイルス核酸量との関你以 対与る比較考察加らして，以上の速断猃に刘して我々 は叟問を抱いて来た。此展好アッ゙ール封入体の組織化 学及び電县頁像から，ウイルス感染により細胞側で合成， されたDNA プールがウイルス粒子完成に先行し，ウ イルス核酸の組村となるでるるらと老察し度い。

細藏ウイル ス増殖機構に就いてのモデル寒鈳によれ ば，核酸の宿主内注入に続いて，芝を中心としたウイ ルス産生が予想されるにる拘らず，現在の処核㖹を含 んボ末热ウイルスが $\mathrm{F}^{32}$ を用いての迫求て捕宗らず， 寧る之を含まない未领垡が証明されている。この一兒 矛盾した知見に刘して，我々の得た未熟型りイルスと

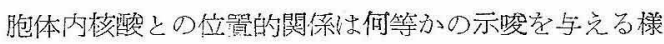
に思われる。俳る此所見る゙好アッ゙ール赴入体辺緣万至

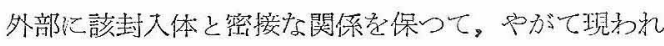
る淡青勢入体並にその表面に吸㛺されて認められるウ

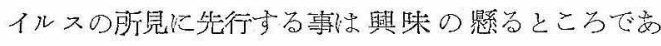
万。

\section{4. 特に淡青封入体の雪顕的搆造に就いて}

好アジール封入体は次第に構造が稀薄不正形化する

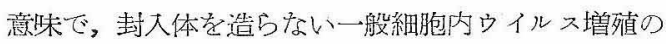
㴍式次第に接近するものと考㝋られるが，淡青封入 体は最後迄次第に発育する。佂つて，本症特有の封入 体として，改めて去の発育段階に就いて検討を加党て 沶く必要が要る。

淡青封入体の名は最初ギムザ染兒時に淡青を旺する

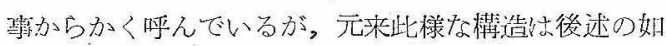
く蛋白笙マトリックスであり。電子濃度文びウイルス

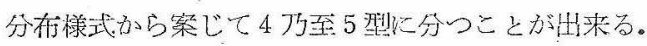

(第 3 図)

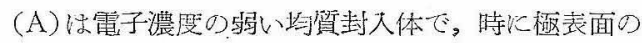
みが濃く，此表面に成熟らイルスが政に吸着して存す

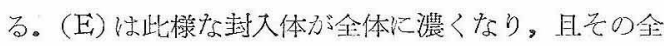

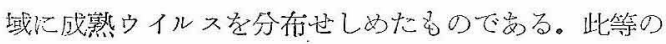

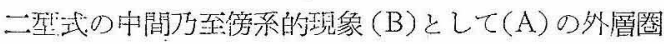

Text-Fig. 3. Schematic diagrams representing the development of the pale bluish staining inclusion body and its corredation ectromelia virus.

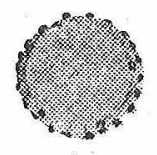

A

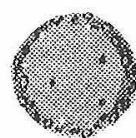

B

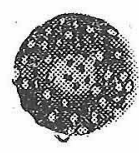

C

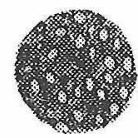

D

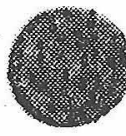

E

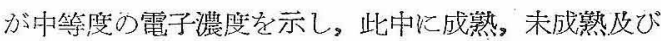
空胞状ウイルスの三者が潉在したものである。(C)K 於ては先の外圏圏が厚く発澾したもので交る。文(D) は(B) 型の外層圈が完全に全封入体に收んだものであ

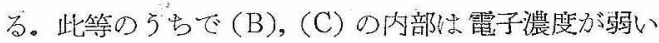
にも拘らず，成㷫型のウイルスが少数散在し，明が 椅円乃至㷄瓦状の形態を察わしぬている. (D)は(B),

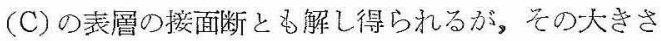
が頗る大き㳘場合も認められるので、これを単なる接 面断的存在と見做し難いので，独过せしめ一つの型と したのでまる。

现。此等の中最当理解学困難ならしぬたのは，今回

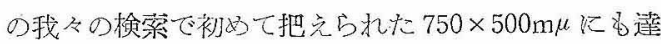

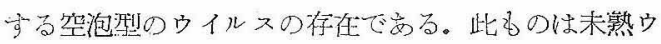
イルスとの間に大ささ㪀び内部密度の点に於て移行性 が赖められ，未熟りイルスゆ变性型と解することも可

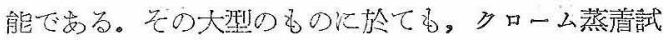

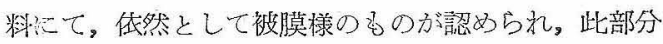
には粒状物が二層並んで明が周国と異なつた性犋 を示している。然し，此部分の倹討によつても，既沉 巨大な金泡に迋したものでは，再び発芶様の賦活現象

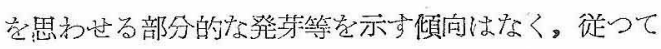
大型空泡状のるのが新断裂して㭃弱的イスに賦活 せられると解すべき所見は把光られず，のみならず大 珰然泡は封大体表面より脱落してゆく像をる示してい る。故以泡状のウイルスは来熟型が偶《成熟への道を

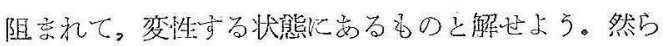
ば何故以淡青封大体汇此榜なるのが高展珄じて来る か，我々の観察を以てすればっウイルスの剩敦による

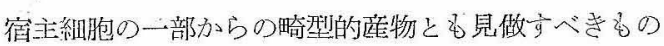
である。即ち，細胞質の合成酵素系は好アジール封入 体では，好アッ゙ール物薋（前にその DNA に当ること 表述べた）を専ら合成する方向に進められるに対し， 淡青封入体では淡青色炕染臽する（後化々の主体が蛋 白であることを述べる）物筧の方向隹行する。而む 後都は単純な蛋白ではなく，電子淟度の次第に增して 来るものでは，之文後に論ずる如く、核酸物質の 浱入度を増して来るもの之解される。

従つて淡青封入体に於けるウイルスの意義は， 最初は先ず細胞の一部權造（之を前回は系粒体之 解したが，此場合これを否定すべき理由は得てい ない）に附箐した成熟型ウイルスによって，封大 体マトリックス合成が出発也しめられる票好文 


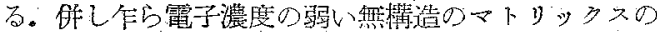
合成が急速潐展寸るに於てに，ウイルス合成必要

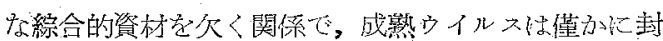
大体表層の電子濃度の強い部分で增殖を営总に止等ら ぜるを得ない（A)型。然し何等かの条件で，封入体形 成の初期からマトリックスの電子濃度が強心場合には

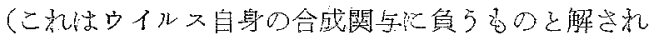

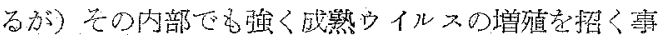
が出来，之が即ち( $(\mathrm{E})$ 型比当るものであるが，この場 合のマトリックス合成は弱く、故比封入体の大きさが 相当化制限されている様で变る。

他方，大型の淡青封入体は尃らマトリックス合成が 先行し，然る後尚る時期から表層少イルスの增殖が起 るにつれて，電子濃度の㮐強い外䁲圈学作り、ここに 未熟ウイルスを㩁する域を現出する。然し，此㥞化霞 子濃度の弱いマトリックスとして急速炕発育した封入

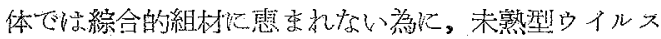
の多くが次第に abortive form となり変性，架泡化し て行之ものであるう。

結局，架泡型ウイルスの発現は淡青封入体の急速な マトリックス発育に伴う偏寄した組材構成の為に未熟

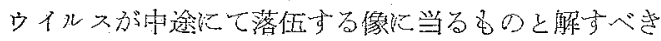

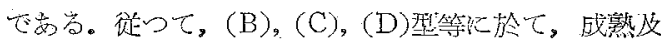
未熟ウイル久学擁ずる電子濃度の中等度の圈が，同時 に空泡型ウイルスの分有を示していることとなるので ある。従つて好アッ゙ール封入体と淡青封入体と細胞 内ウイルスの偏寄した合成刺战の二型を極端沰表方す

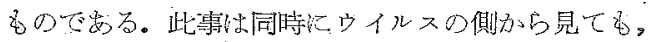

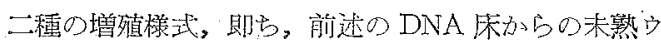
イルスのケォス的発生と斯る未熟瑟ウイルスの泛しい 增殖様式を表わするので禹る。

\section{5. 淡青封入体中の各種ウイルスに就て}

次に淡青封入体中の亘大な堮泡然的イルスに就て は，今少しくウ1亿構造諭的飞検討して冝く必要が 支る。此種の粒子妘好アッ゙ール封入体の末期汇於て。 細胞賀内にも嚾少散見されることも岁るが，原則的炕 は淡青封入体の (B)，(C)，(D) 型潗団的纪認められ

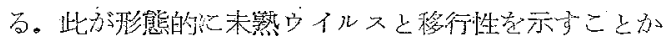

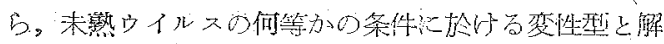
すべき椠は既に述べて置いた。

従来か・不完全ウイルスの形態比就いての資料が提

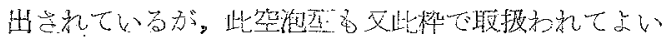

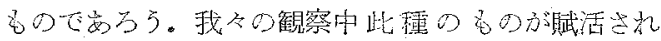

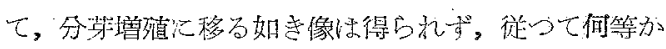

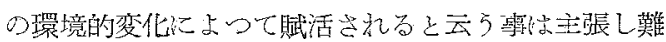
い。

䨤も角，好アヅール及淡青封入体を通じて，前者の 中に，(1) 内容の電子濃度の低心，殆ど限界膜の久の

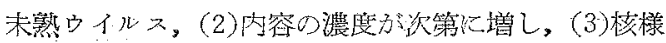

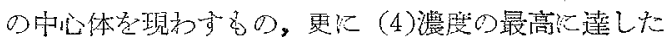

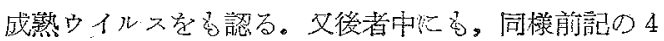
種類のウイルスを認めるので岕るが，前項仙述べた条 件の為に，或物城熟型家もつ小型のものとて止り， 又或物は此等 4 種定同時㒕与る大型のものとして現

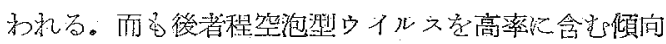
がある。又一個の癌細胞内纪多数の淡青封入体を容れ る場合には，(B)，(C)，(D) 妍のものによって占めら れている罢も此聞の関係を表わすものと云光よう。斯 る特徵は溳細胞の特性とする蛋白合成系と応じてマト リックスの急速な発充が可能であることと関連してを り，今後生化学的汇興味起抱加世方面であ万弓。

掞，空泡型の的ルスは、インフルエンザウイルス

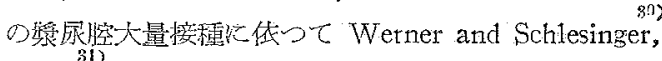
深半氏等の得た不全型ウイルスと同解貼比这つるのか は今後の閣題である。

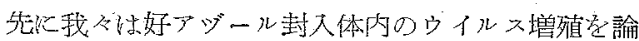
じたが。淡青埗大体でも別値にウイルス成熟過程が道 求されるから，此等を仮に夫之ウイル又堌殖の第一，

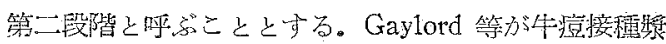

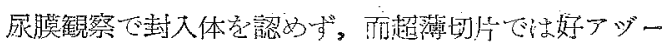
儿封入体汇該当する像を得ている等は。第一段階を証 明し得て，而もこ礼加ら第二段階记移行する何等加の 条件の缺除しているもの之云らべく, 我必此点以興 味学賞光る。先俄及が指摘した如く、エクトロメリ 感染肝細跑方封入体形成能弱〉。而已電顕的记好了 ジール垛入体型の像を呈していることも亦これ之類同 的㶤解せられよう。

\section{6. 淡青封入体之細胞化学}

此淡青封入体の化学的組成阔しては，我々は腫瘍 形成部 (腹壁) 切片標本て Feulgen 反応陽性を得。

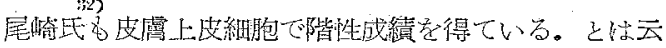
光。必ずしる封入体全部が常に陽性でない專も撃然 で。染枺標本では好アッ゙ール封入体の陽性と買なり陰 跣で岕る。現在迄得られた我々の成績㥸依れば。淡青 封入体は PAS 染色伩びTol tidinblue のメタタロマジ 一区流でも。媒筫の $\mathrm{pH}$ 值変動下で陰性飞終始し，脂 
Text-Fig. 4. Diagrams representing the multiplication of ectromelia virus within the two types of inclusion blodies, azurophilic and pale bluish.
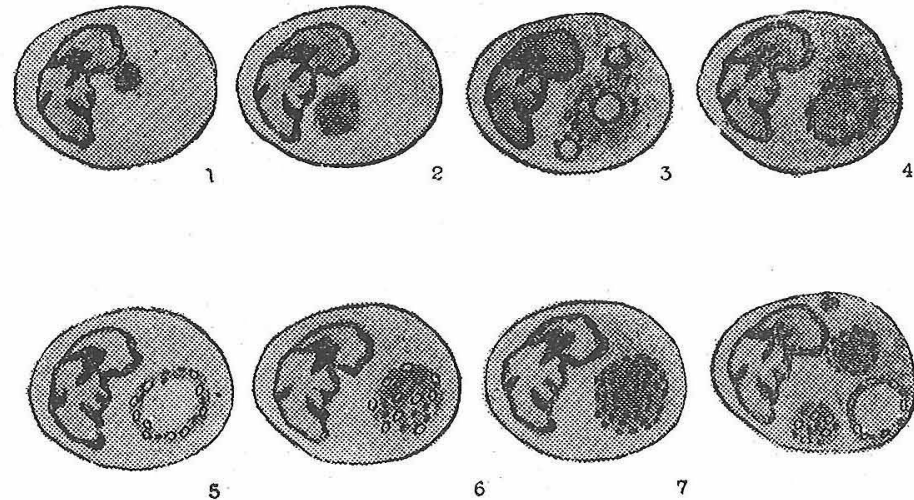

6

肪類も含まない。只精度は低いが，確实な蛋白度応た るどューレット及びミロン反流陽性を示す。従つてこ の封入体基筫は我々の賞て予想した蛋白を多量に含む 桨分明がなつた。此点 van Rooyen (1939) の伝染 经軟皆腫封入体及び三夰氏（1953）のトラコーマ小体 に於けるグリコーゲン陽怔所見と比較して义暴つた興 柴る呼ぶものがある。

䍩っこの組織化学的所見を電顕像と比較老察すれば, 電子濃慰の低い基筫は蛋白と同定される。成熟型及未 成熟型ウィルス，贯に大型空泡が常に電子濃度の高い

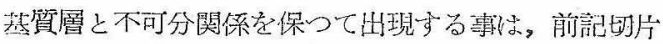
標本の Feulgen 反応陽性所見と併せて，茼同封入体 の DNA 分布汇就て，何等かの術式に上り，新な伤度 から検討学加光るべきであるう。(第4 図)

\section{V. 結 論}

1. エタトロメリア・ウイルスはエールリッヒ癌細 胞貿に大別二種の封入体，即，1. 好アジール ル封入体文 淡青球状封入体走形成しつつ增殖 し、癌細胞を破壞 し、その発育を抑制する。

2. 該封入体の形態学的特徴に就いて。特に細胞化 学的並に電子顕微鏡に上る柖菁切片篗察を考行つた。好 アッ゙ール封入体はDNAを主体としたマトリックスよ

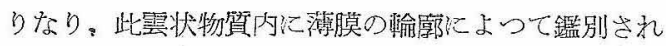
る電子濃庋の甚だ弱い覾々の形の未熟ウィルスの集団

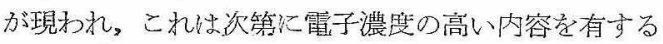
成熟ウイルスへの発育像を認める。

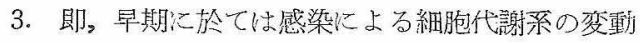
により，先ずウイルス組村たる DNA 物質が細胞筫内

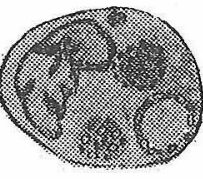

に局処的以合成されっここに前記未 熟型ウイルスの生成が始皂る。

4. 好アジール封入体と密接な関 係の下に，その崩壞期に当つて，淡 青封入体が出現する。同封入体学它 の含むウイルスの分布㥞式低低 て，篦に表面にウイルスを吸着也し わた電子漂度の薄いもの，坟び次第 に内部にゥイルスを満した稍濃度の 高いもの，更に雨者の中間的構造の るのと数樫に分ら得る。

5. 淡青封入体では，内容が単な る蛋白性マトリックスよりなる妁貿 なものに於て，既に表面に成熟計 ルスの吸音像が認められ。そのマトリックスの濃展の 増加応じて，表層から次第に内部亘うてウイルス が分布するに至る。その中，電子濃既の高いものでは 成熟ウイルスが，父弱いものでは未熟の，但し多くは

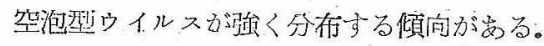

6. 好アジール㭙入体のDNAマトリッタスと云い， 淡青封入体の蛋白マトリックスと云い，何れ子細胞内 ウイルスの兽殖と関連して，宿主細胞酽素系の関与が

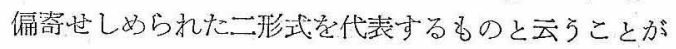
出来よう。

電子顕徽鏡観察に御援助を与兄られた宗大東助教 授，同小林助教㥅及び島津慗作所外村技師並びに協同 研究者岩片氏に刘して深謝する。

最後に御指導, 御校閲孛得た天野助教授に深謝する。

\section{交献}

1）土肥清一：ウイルス性疾忠飞於ける封入体の biology 関与る研究。第 1 報。エクトロメリア封 入体婂就いて。VIRUS, $1: 127$ 133, 1951. 2) 土肥浩一：ウイルス性疾患沉於ける封入体のbiol-

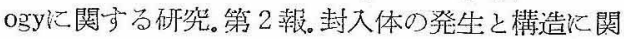
する位相差典影微鏡学的研究, VIRUS,3 : 307 313, 1953. 3) Levaditi, C. and Nicolau, S. : Vaccine et néoplasmes. Compt. Rend. Acad. Sc., $174: 16$ 49 1652, 1922. 4) Turner, J. C. and Mulliken, B. : Parasitization of mouse sarcoma 180 by vaccine virtus and its effect on tumor growth. Canc. Res. $7: 774 \sim 778,1947$. 5) Scherer, W. F. and Syverton, J. 'T. : The viral range in vitro of a malignant human epithelial cell. (Strain HeLa, Gey) 1. Multiplication of herpes simplex, pseudorabies and vaccinia viruses. Am. J. Path., 30 : 1057-1074, 1954. 6) Bang, F. B. and Gey, G, 
O. : Comparative susceptibility of cultured cell str ains to the virus of Eastern equine encephalomyelitis. Bul1. Johns Hopkins Hosp., 91 : 427-461, 1952. 7) Ackermann, W. W. and Kuntz, H. : A new host-virus system. Proc. Exp. Biol. and Med., 81 : 421-423, 1952. 8) Wagner, R. R. : Influenza virus infection of transplanted tumors. Canc. Res., $14: 377-385,1954.9$ 9) Koprowska, I. and Koprowski, H. : Effect of Mengo encephalitis virus on the Ehrlich ascites tumor of the mouse. J. Nat. Canc. Inst., 14 : 627-644, 1953. 10) Koprowska $I_{0}$ and Koprowski, H. : Morphologic and biologic changes in a mouse ascites. tumor following induced infection with certain viruses. Canc. Res., 13:651-660, 1953. Love, R., Koplowski, H. and Cox, H. R. : Cytological studies on the Ehrlich ascites tumor before and after infection with Runyamwera virus. Canc. Res., $13:$ 350-356, 1953.

Koprowski., H., Koplowsiki, I. and Love, R. : Ascites tumor-virus system as a biological tool Proc. Nat. Acad. Sci., 39 : 1147-1149, 1953.

13) 天野雷安，土肥清一，岸暂雄：ウイルス性炎

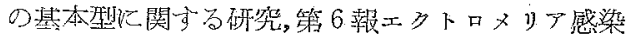
の病理, 日病会誌, $41: 202 \sim 203,1952$. 14) 一天 野電安, 土俋清一：エクトロメリア・ウイルス感染 細胞の形熊学的研究，.ウイルンの総合的研究泎報 告。眧和29年 (印删中) 15) Latt, H. and Hartmann, F. : Use of a glass edge in thin sectioning for electron microscopy. Proc. Soc. Exp. Biol. and Med., 74:436-438, 1950. 16) Klein, G. and Révész, L. : Quantitative studies on the multiplication of neoplastic cells in vitro. 1, Growth curve of the Ehrlich and MCIM ascites tumors. J. Nat. Canc. Inst., $14: 229-279$, 1953.17 ) Luciké, B. and Berwick, M. : Quantitative relation between growth of Einrlich ascites tumor and reduation of liver catalase activity. J. Nat. Canc. Inst., $15: 99-112,1954$. 18) Seiby, C. C., Gey, C. E., Lichtenberg, S., Friend, C., Moore, A. E. and Biesele, J. J. : Submicroscopic cytoplasmic particles occasionally found in the Ehrlich mouse ascites tumor. Canc. Res., 14 : 795-801,1954. 19) 永田育也，小野三郎，腵部於菟吝：ウイルスと腫

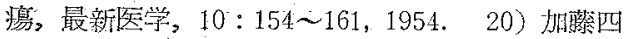

郎：細菌学会西部坜方会発表吱私信，1954

Morgan, C. and Wyckoff, R. W. G. : The electron micrography of fowl pox virus within the chorio-allantoic membrane. J. Immunol., 65 : 285295, 1950. 22) Gaylord, W. H. and Melnick, J. I. : Intracellular forms of pox viruses as shown by the electron microscope (vaccinia, ectromelia, molluscum contagiosum). J. Exp. Med., 98 : 157171, 1953.23$)$ Dowson, I. M. and McFarlane, A. S. : Structure of an animal virus. Nature, 161 : 464-466, 1948. 24) Leventha1, C. and Fisher, H. : The structural development of bacterial virus. Bioch. et Bioph. Acta, 9, 419-429, 1952.

Hydén, H. : The nucleoprotein in virus reproduction. Cold Spring Harbor Symp. Quant. Biol., 12 : 104-114, 1950. 26) Caspersson, T. U. : Ce11 growth and cell function. W. W. North, N. Y. 1950. 27) Wolman, M. : On the absence of desoxyribonucleic acid from some chemically-induced cytoplasnic and intranuclear inclusions, with reference to a special type of false positive staining by Feulgen's nuclear technique. J. Path. and Bact., : 159-164, 1954, 28). Scott, T. F. Mc Nair, Blank, H., Corie11, L. L. and Crouse, H. : Pathology and pathogenesis of the cutaneous lesions of variola, vaccinia, herpes and varicella. "The pathogenesis and pathology of viral diseases." edited by Kidd, J. G., Col. Univ. Press., 7398, 1950. 29) Maal $\phi$, O and Symonds, N. : Radioactive sulfur tracer studies on the reproduction of T4 bacteriophage. J. Bact., $65: 177-182,1953$. 30) Werner, G. H. and Schlesinger, R.W. : Morphological and quantitative comparison between infectious and non-infectious forms of influenza virus. J. Exp. Med., 100:203-216, 1953. 31) 深

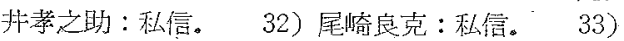
van Rooyen, C. E. : The chemical composition of the molluscum contagiosum inclusion body. J. Path. and Bact., : 345-349, 1939. 34) 三井幸㼂,

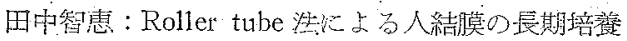
とトランーマ・ウイルスの培養実験, VIRUS, 3 : 198-199，1953. 35）土肥清一：土タトロメリア感

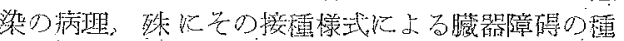
々相, VIRUS, 2 : 131 139, 1952. 


\section{Explanation of plate}

All photographs show Ehrlich mouse ascites tumor cells which are infected with ectromelia virus.

Fig. 1,2. After 72 hours: The azurophilic inclusion bodies are seen in cytoplasms which are scattered with small fat droplets and whose basophility are not declined. The inclusion is apt to take place near the nucleus. The inclusion within the right upper cell (Fig. 1) possesses the indistinct edge. The right upper cell (Fig. 2) contains two inclusions on the both sides of the nucleus. Giemsa's stain. $\times 1570$.

Fig: 3. After 96 hours: Two pale bluish staining inclusion bodies in contact with a diffusely formed azurophilic inclusion body are seen on the right side of the nucleus. Giemsa's stain. $\times 1570$.

Fig. 4. After 5 day: Typical pale bluish staining inclusion boties are present in most cells. Giemsa's stain. $\times 1570$.

Fig. 5. After 5 days: The cell shows several inclusions containing numerous elementary bodies and shows a diffuse blister. The inclusions have considerable variation in diamete: Phase contrast microscopy. $\times 1570$.

Fig. 6. After 96 hours: A typical inclusion body and two irrezularly shaped dense bodies compatible with the azurophilic inclusion are present near the nucleus. The cell is scatteref with mitochondria and some fat droplets. Phase contrast microscopv. $\times 1570$.

Fig. 7. After 72 hours: There are mitochondria characterized by their internal structures, and homogeneous granules which compatible with fat droplets, and endoplasmic reticulums as scattered within the cytoplasms. Chrome shadowing. $\times 5220$.

Fig. 8. After 72 hours: At the right perinuclear zone several azurophilic inclusions are present. They contain some mature viruses and many developmental bodies which represent the characteistic internal structures. Chrome shadowing. $\times 5830$.

Fig. 9. After 72 hours: Immature viruses within the irregularly formed A-inclusion in the lower part of the left cell. Note some mature viruses in left upper. Chrome shadowing. $\times 8700$.

Fig. 10. After 72 hours: There are developmental bolies characterized by membranes surrounding homogeneous material of low electron density within the area of more increased density than the cytoplasm. Mitochondria are distributed around it. $\times 10440$.

Fig. 11, 12. After 72 hours: There are developmental bodies which show thin boundary membranes surrounding centrally or excentrically located granules (central body) in the azurophilic inclusion. Fig. 12 . illustrates the various central bolies. Chrome shadowing. $\times$ 8700. (Fig. 11), $\times$ 20000. (Fig. 12).

Fig. 13. After 96 hours : Two round homogeneous B-inclusion bodies lie in contact with a amorphous A-inclusion on the left side of nucleus. Mature viruses attached to and surrounded the former which are structureless and low to elecron density. The latter, containing the developmental bodies in various stage of maturation, has indistinct edge. Note swollen mitochondria and localized ergastoplasms. $\times 6960$.

Fig. 14. After 96 hours : An inclusion of low density, containing oval shaped vacuoles 500 to $750 \mathrm{~m} \mu$ in diameter, is in touch an area occupied by closed pacising of immature viruses in various developmental stages. Near the lower border of the figure lies. a cluster of round granules whose size are a little smaller than ectromelia virus. $\times 6960$.

Fig. 15. After 5 days : There are two round B-inclusions with adherent mature viruses within the cytoplasm. Some viruses are distributed diffusely in the cytoplasm. In the left large inclusion the density of peripheral zone is higher than the inner portion. $\times 8000$.

Fig. 16. After 5 days: In the upper half of this figure lies a inclusion whose peripheral zone is comp- 
osed by closed packing of fine granules. No particle corresponding with virus is found within it. Swollen mitochondria and ergastoplasms are present in the left border. Chrome shadowing. $\times 8700$.

Fig. 17. After 5 days : A large B-inclusion occupied almost half part of the cell. It is clear cut divided in two parts, namely, (1) the outer dense zone containing many empty looking immature viruses and large vacuoles, (2) the inner less dense one, containing few mature virus. Chrome shadowing. $\times 6790$.

Fig. 18. After 5 days: In the B-inclusion it appears that the outer dense zone expands toward the center. The large vacuoles in this zone show variation in volume, shape, internal structure and thiciness of enclosing membrane. At the left border some mature viruses and tranditional bodies may be seen. In the central zo e there is a greater number of oval or brick shaped viruses than in Fig. 17. Chrome shadowing. $\times 15660$.

Fig. 19. After 5 days : For the four inclusions the same relation of inner electron density holds as for those in Fig. 17. However, a majority of virus particles in the outer zone belongs to the mature type and only few large vacuoles are present. $\times 12180$.

Fig. 20. After 5 days: At the left border lies a relatively dense inclusion body which is filled up by the large vacuoles, few mature viruses and few developmental bodies. $\times 8700$.

Fig. 21. After 5 days: This figure illustrates a inclusion with its whole interior occupied by large number of the vacuoles. The enveloping membranes also show the fine granilar structure. Chrome shadowing. $\times 10880$.

Fig. 22. After $\mathbf{5}$ days : Four inclusions demonstrate varying struatures in a single cell. Swollen mitochondria can be seen around the upper right inclusion. $\times 6960$.

Fig. 23, 24. After 5 days: Two typical inclusions show the homogeneous dense inner ground material diffusely distributed by virus particles belonging mainly to the mature type. They demonstrate that the number of mature viruses is parallel to the electron density of inner matrix. Fig. 23. $\times 9740$. Fig. 24 . Embedding material was removed. $\times 8700$. 
土肥論攻附図 1
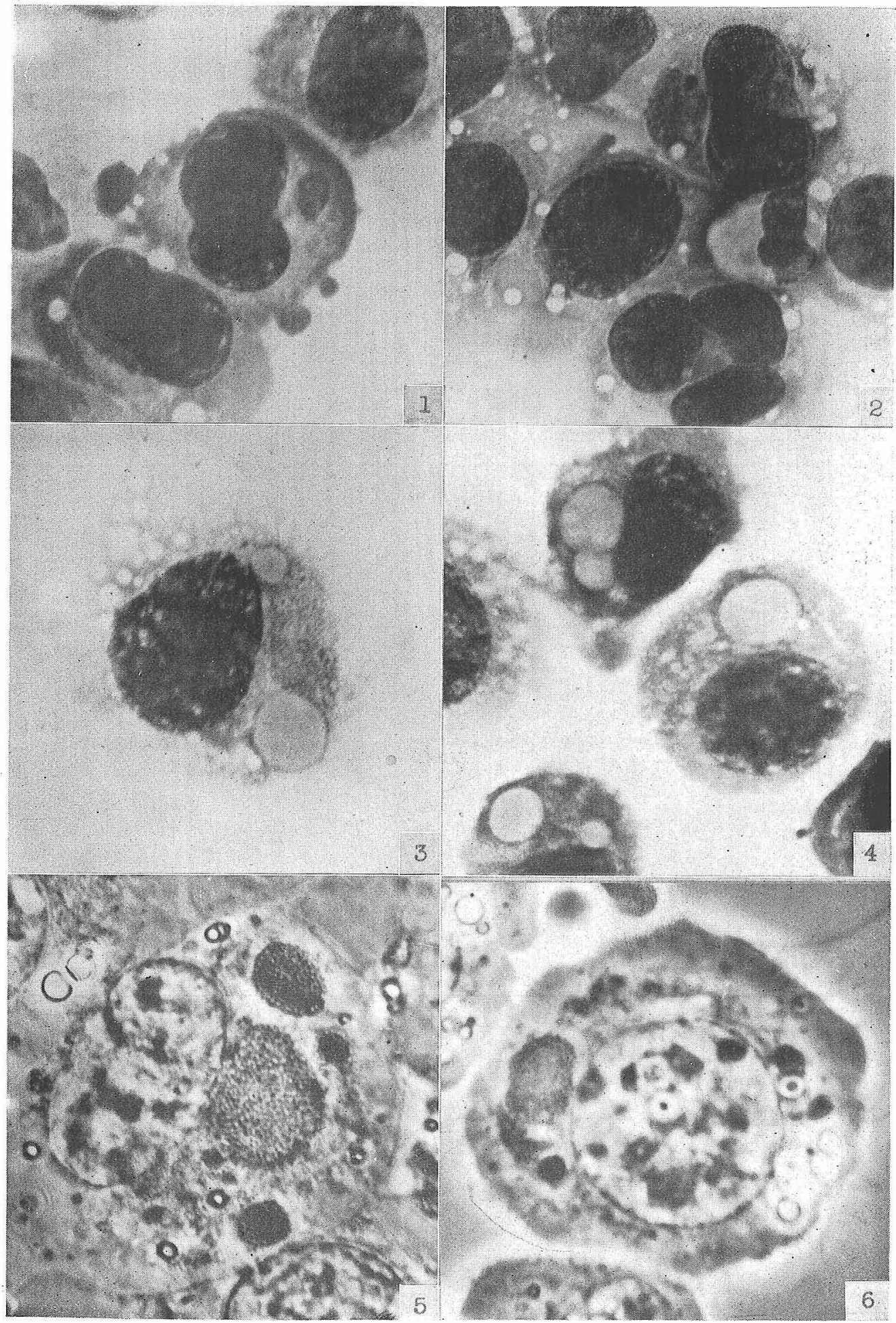


\section{上肥論交附図2}

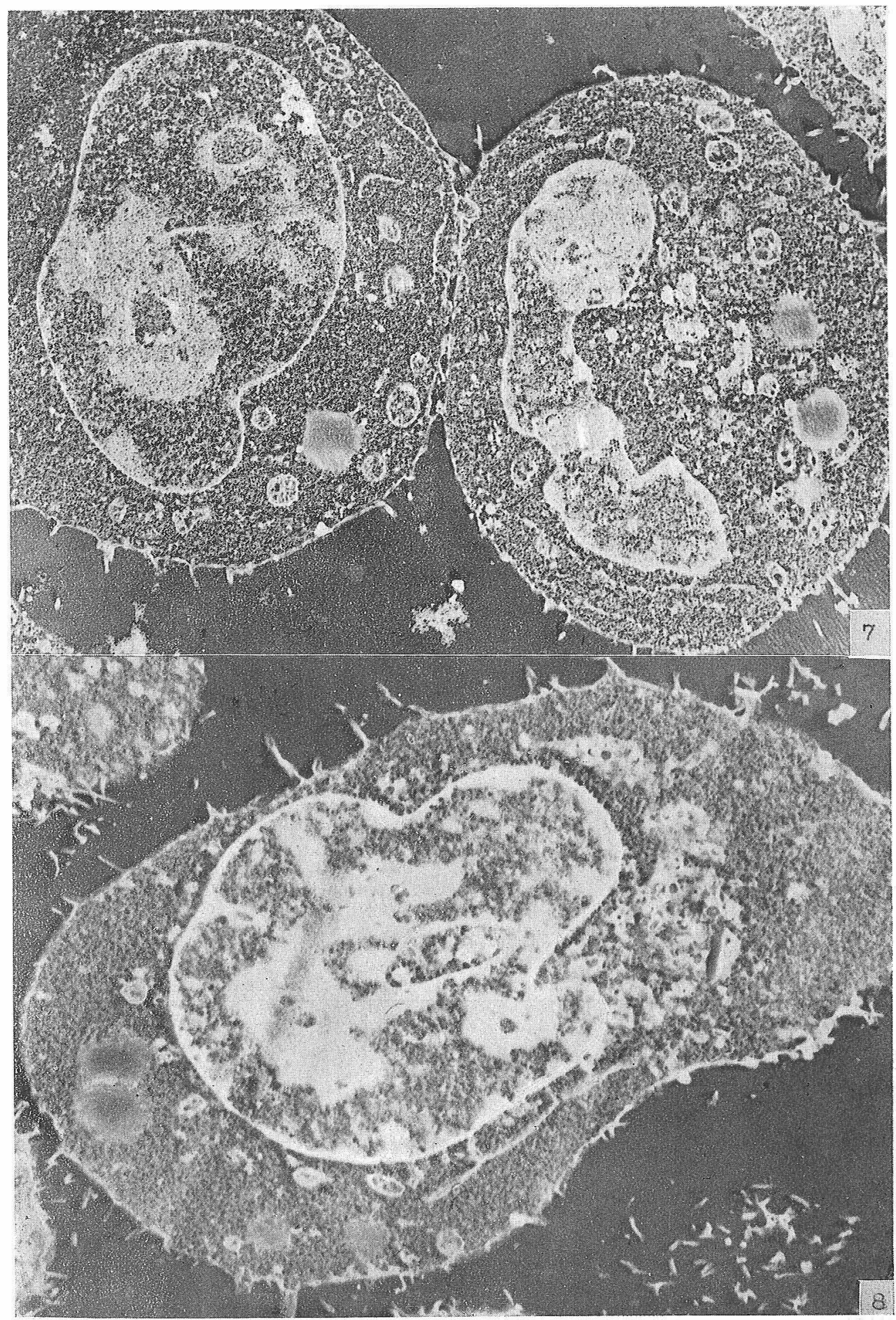




\section{土肥論文附図 3}

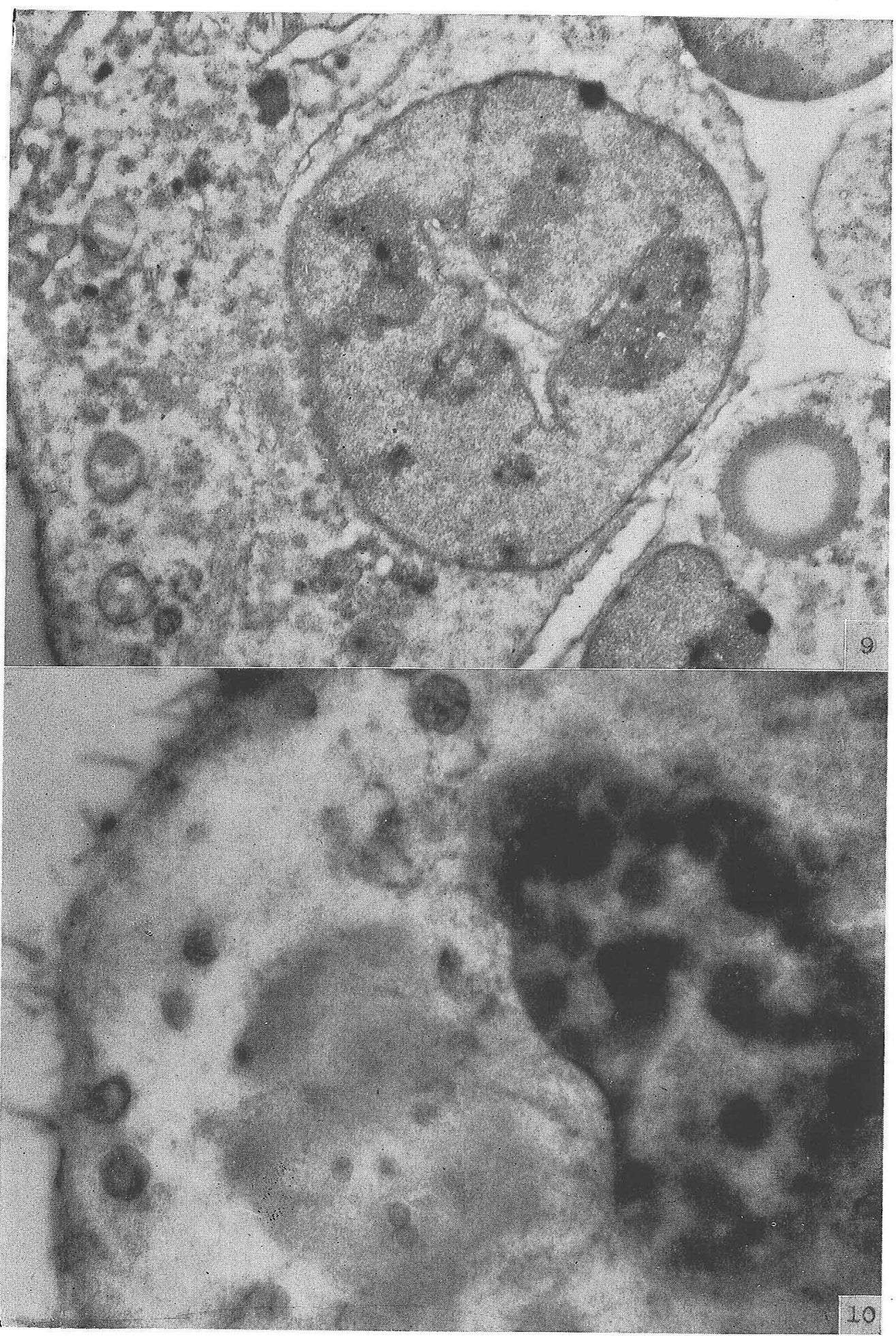




\section{土肥論交附図 4}

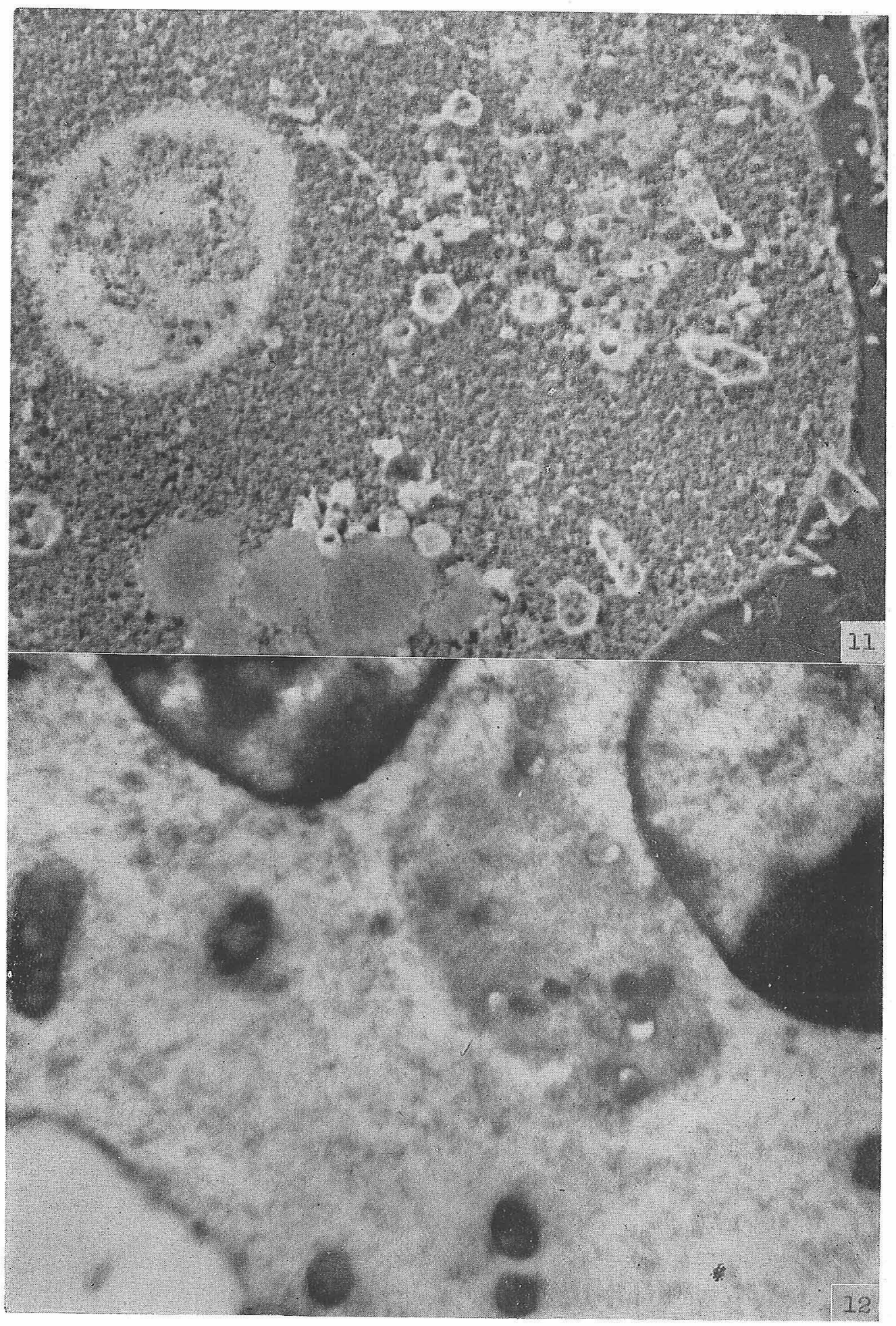




\section{土肥淪交附図 5}

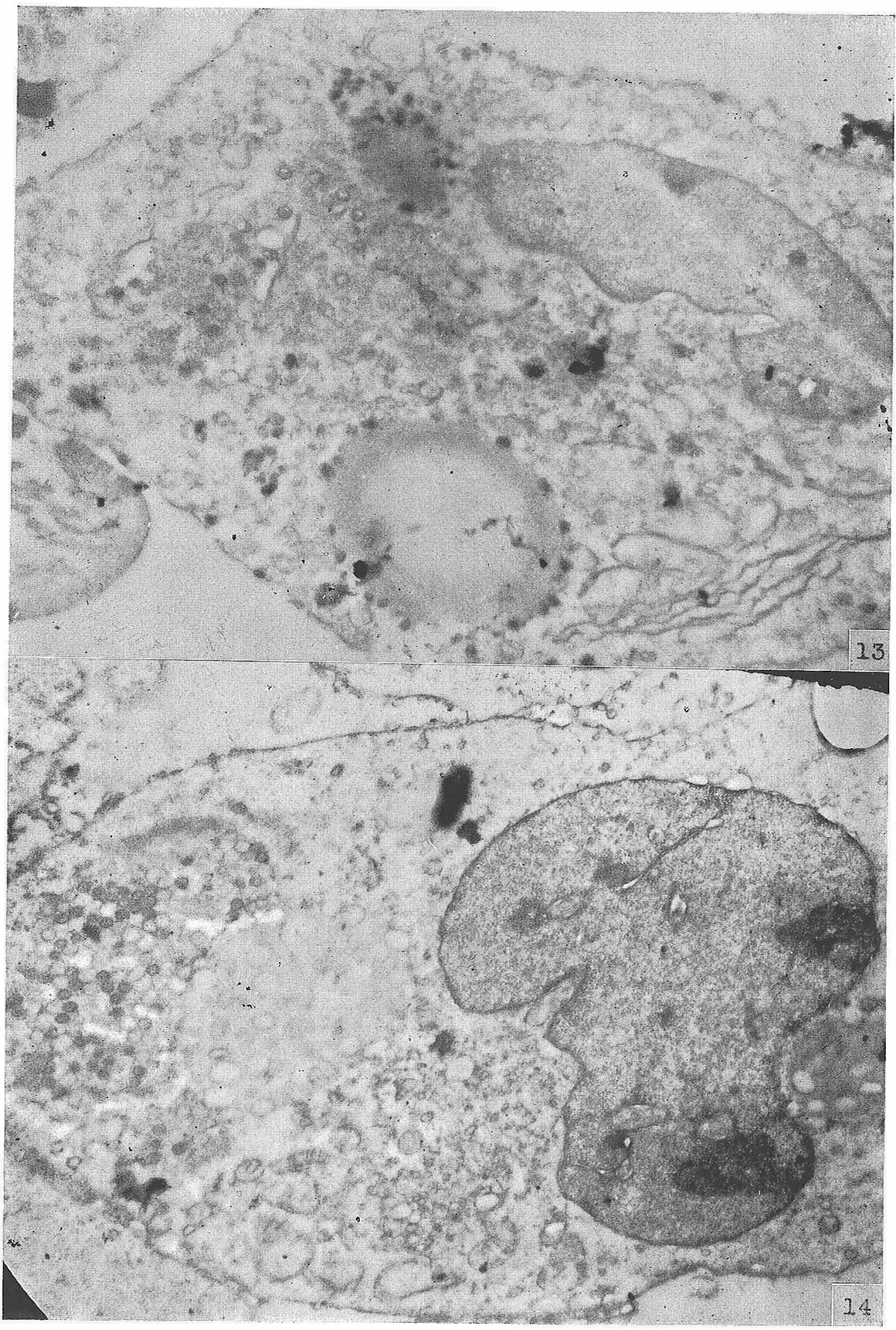


土肥 論 文附図 6
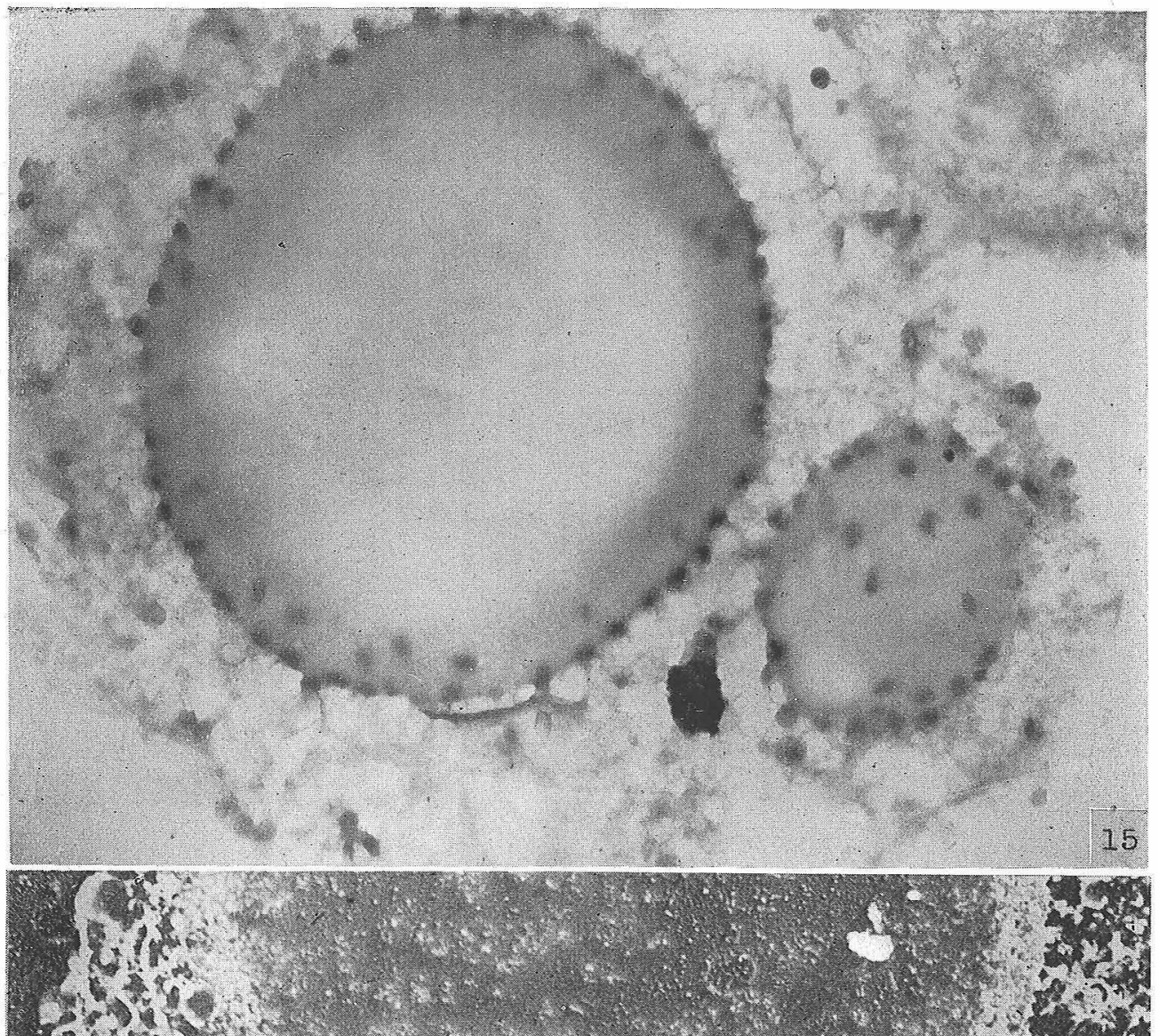

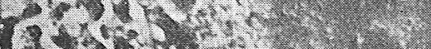

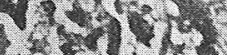

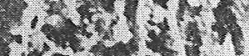

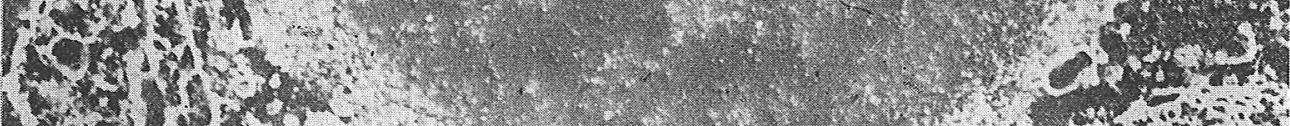

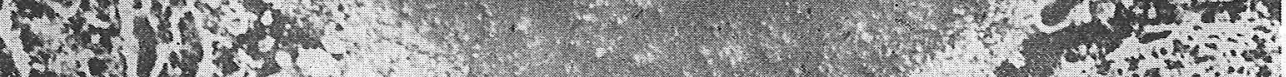

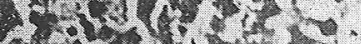

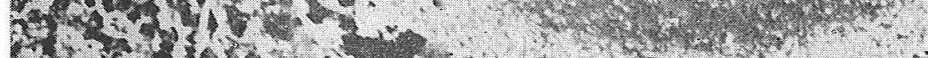

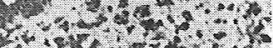
2.

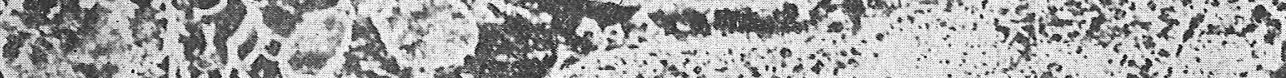

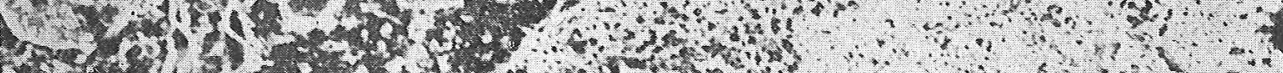

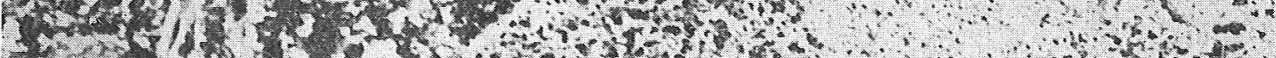

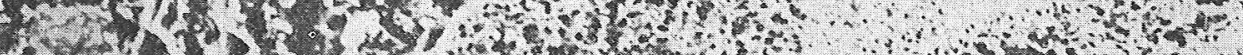

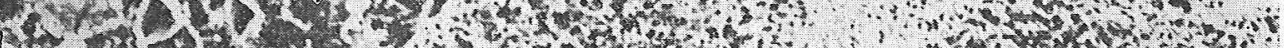

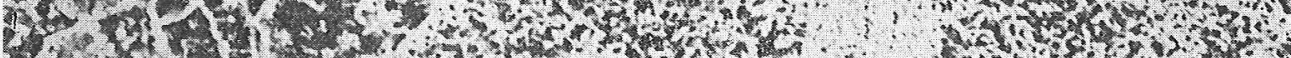

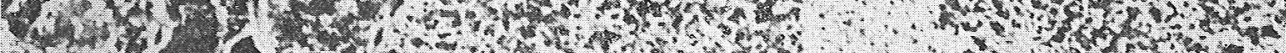

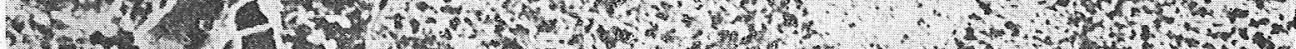

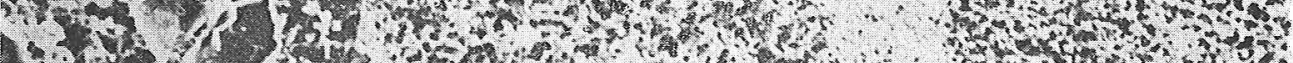

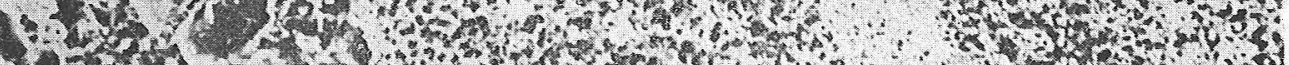

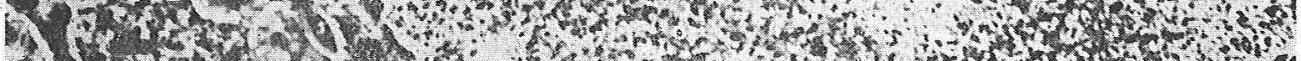

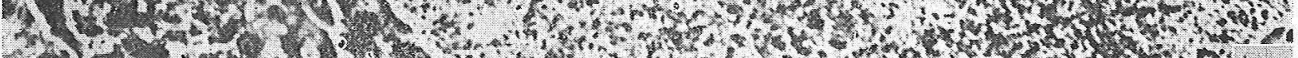

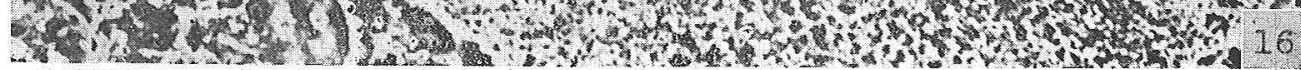


土肥論文附図7




士肥論文附図8

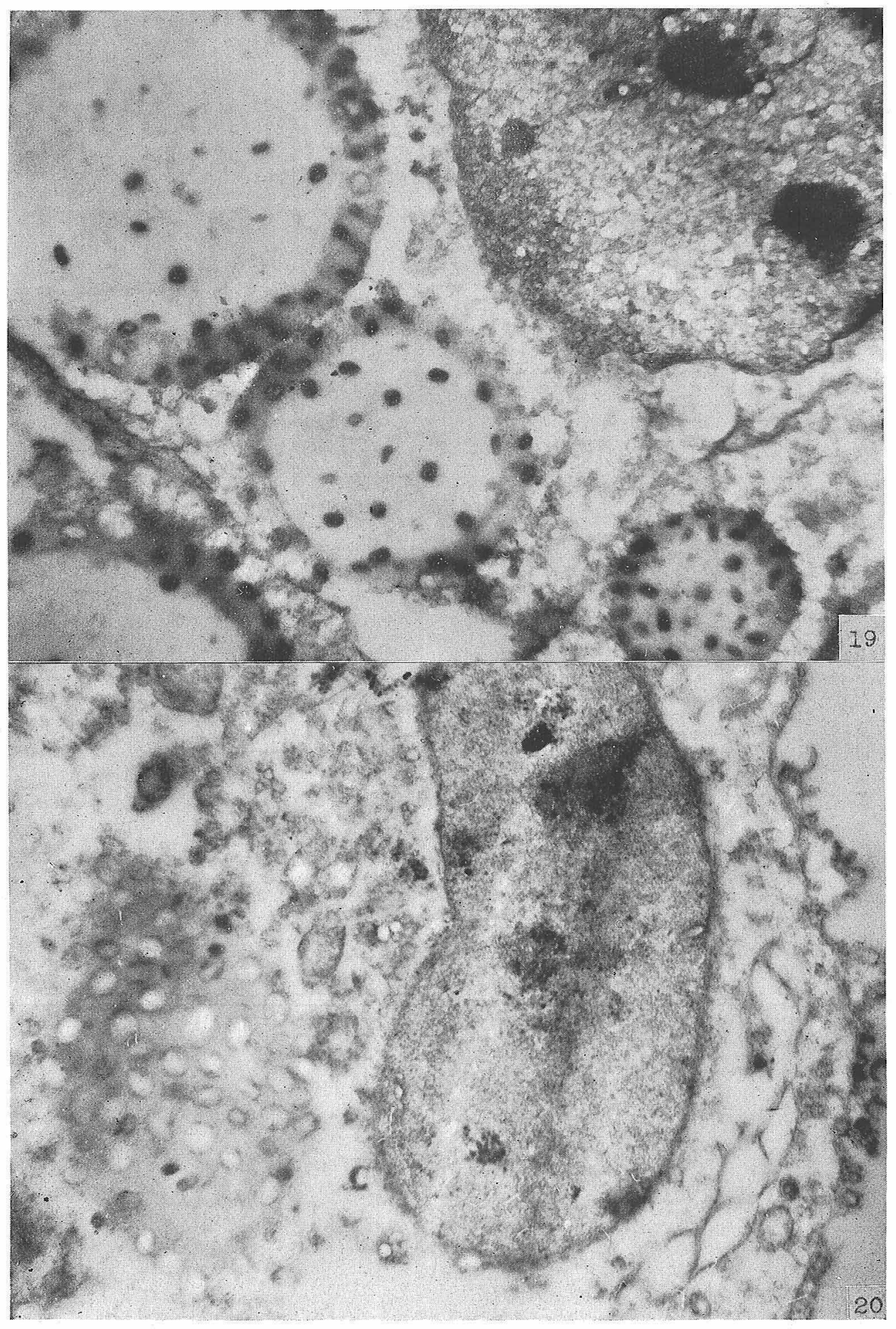




\section{土肥 論 交附闵 9}

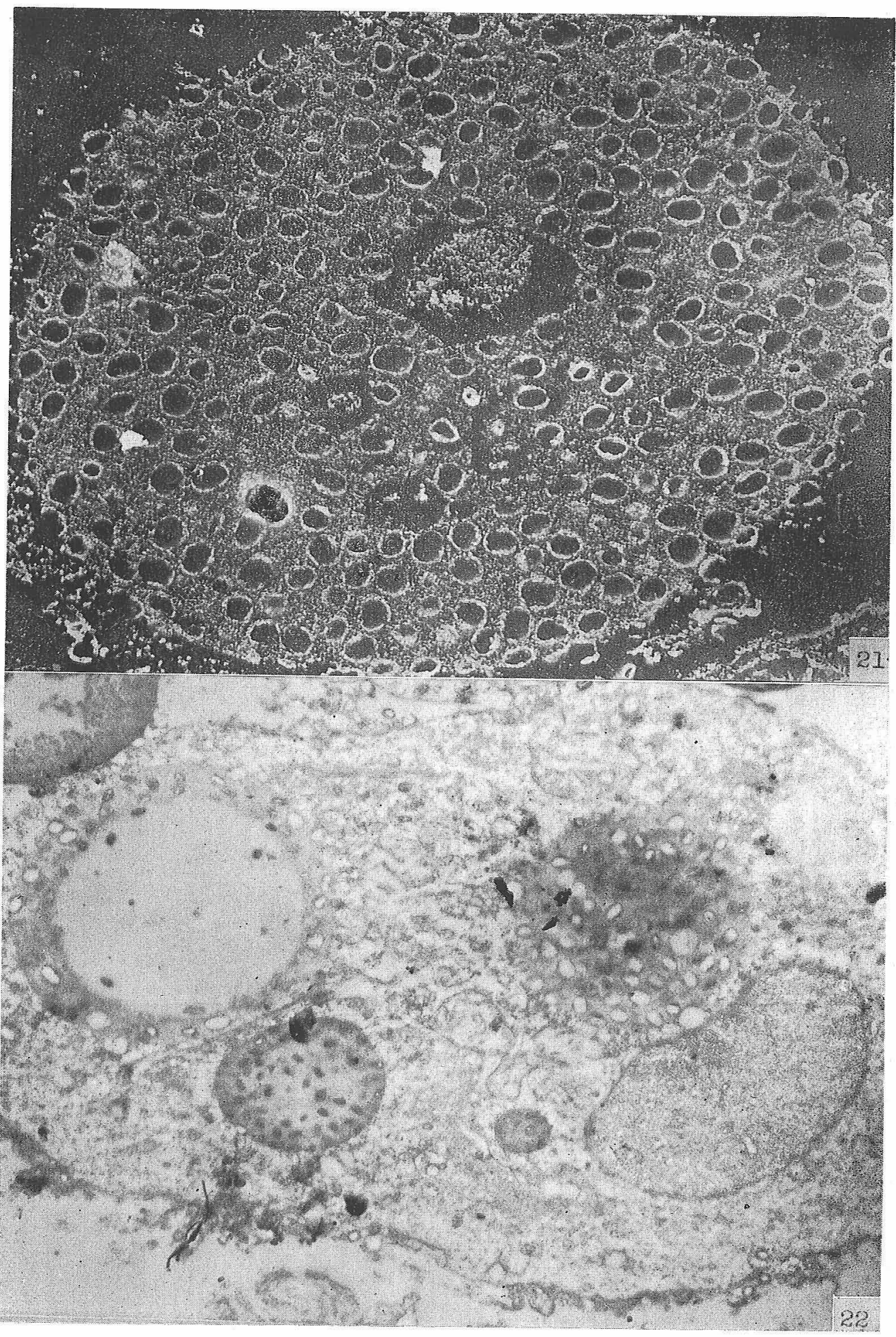


土肥論交附図 10

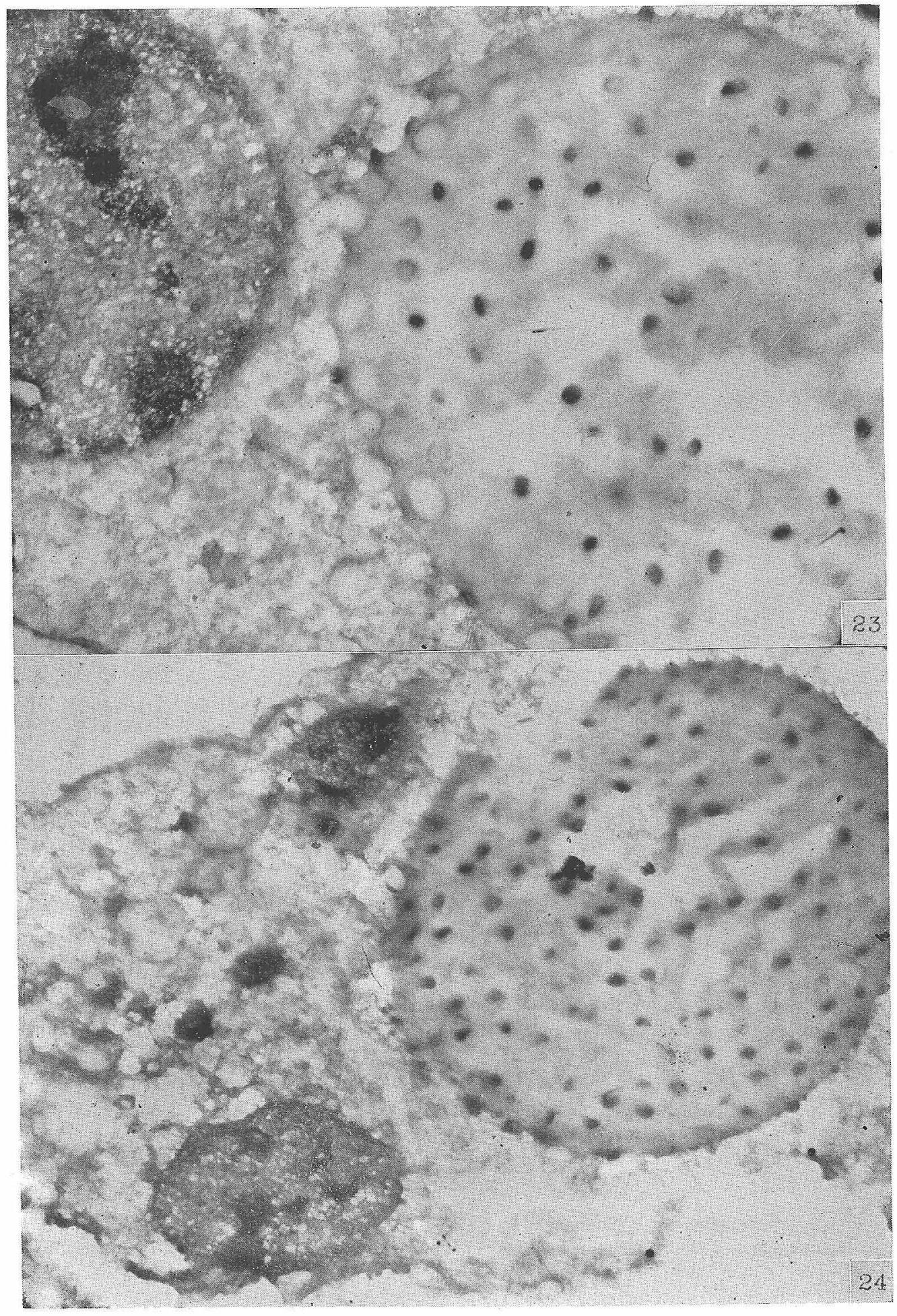

